\title{
Syntéza kreativního učení a vzdělávání pro udržitelný rozvoj v České republice
}

\author{
Laura Henderson, Michaela Kuř́íková, Roman Kroufek \\ Envigogika 16 (2) - Recenzované články / Reviewed articles
}

Published/ Publikováno 21. 12. 2021

http://dx.doi.org/10.14712/18023061.628

\begin{abstract}
Abstrakt
Tento článek pojednává o pedagogickém př́stupu Vzdělávání pro budoucnost (VpB) propojujícím dva vzájemně provázané podpưrné modely kompetencí: Klíčové kompetence pro udržitelnost (Rieckmann 2017) a Kreativní vzdělávání a model Kreativní návyky mysli (Lucas, Claxton, \& Spencer, 2013). Uvedený př́stup se týká některých problémů implementace vzdělávání pro udržitelný rozvoj tím způsobem, kdy žáci sami stanovují svou vizi a svůj závazek k provedení změny. Mezi tyto problémy patří: 1) Ekologické vzdělávání se i nadále vede v duchu scientismu, který neumožňuje žákům pochopit sociální a společenské souvislosti hlavních př́čin environmentálních problémů a uvědomit si „možnosti konat" vlastní jednotlivcům i společnosti; 2) Může být nedostatečné pochopení způsobu, jakým se budoucnost „přihodi"; 3) Vzdělávání pro udržitelnost často vychází z transmisivních modelů vzdělávání. Je však třeba přejít k participativním, socio-konstruktivistickým, transformativním; 4) Mnoho z kompetencí, které potřebujeme, abychom dokázali čelit problémům 21 . století, se nachází mimo kognitivní oblast, především v oblasti afektivní (UNESCO, 2017). Článek shrnuje, jak se projekt vztahuje k Akční kompetenci (Jensen \& Schnack, 1997) a modelu participace (Lundy, 2007), za účelem vytvoření efektivního př́stupu k rozvoji udržitelných kompetencí a rozvoji sebepojetí žáků jako aktérů změny. Popisuje implementaci pilotního projektu $\mathrm{VpB}$ ve čtyřech tříaách základních škol (1.-9. tř́́da) a pozitivní dopad rozvoje kompetencí u účastníků.
\end{abstract}

\section{Klíčová slova}

Vzdělávání pro budoucnost; klíčové kompetence pro udržitelnost; kreativní vzdělávání; participace; kreativní návyky mysli.

\begin{abstract}
This article discusses the Education for the Future (EFF) pedagogical approach linking two mutually supportive competence models: Key Competencies for Sustainability (Rieckmann 2017) and the Creative Habits of Mind model (Lucas, Claxton, \& Spencer, 2013). The article describes some of the challenges of implementing education for sustainable development in such a way that students themselves develop their own vision and commitment to making change. These problems include: 1) Environmental education continues to be conducted in the spirit of scientism, which does not encourage students to understand the social and societal context of the root causes of environmental problems and to become aware of the "opportunities for action" inherent in individuals and society; 2) Education for sustainability is often based on transmissive models of education. However, there is a need to move towards participatory, social-constructivist, transformative models; 3 ) Many of the competencies we need to face the challenges of the 21st century go beyond the cognitive domain,
\end{abstract}


and are particularly active in the affective domain (UNESCO, 2017); 4) There may be a lack of understanding of the way the future "happens". This paper summarises how the project relates to Action Competence (Jensen \& Schnack, 1997) and the Lundy Model of Participation (Lundy, 2007), in order to create an effective approach to developing sustainable competencies and developing students' self-perception as agents of change. It describes the implementation of the EFF pilot project in four primary school classes (grades 1-9) and the positive impact of competence development in participants.

\section{Key words}

Education for the future; key competences for sustainability; creative education; participation; creative habits of mind. 


\section{Úvod}

Vzdělávání je považováno za klíč ke změně k udržitelnosti, ačkoliv jsme svědky toho, že spousta vysoce kvalifikovaných lidí na silných vedoucích pozicích se vyhýbá jakémukoli vážnému závazku k udržitelnosti. Nepotřebujeme více stejného vzdělávání, potřebujeme jiné vzdělávání (Orr, 2004). Vzdělávání je $v$ současné době pod tlakem neoliberálního ekonomického růstu ${ }^{1}$ a aktivně slouží korporátním zájmům, protože za svůj hlavní cíl považuje pracovní uplatnění (Giroux, 2003). Výuka podřizená standardizovaným testům vychází z étosu soutěživosti a př́pravy na současný pracovní trh. Kurikulum je zaměřené převážně na minulost, ačkoliv se pracovní trh $v$ př́iśtích letech změní (Manyika et al., 2017). Dnes se ve vzdělávání klade hlavní důraz na měěení a srovnávání výkonu, je ale třeba vrátit se k otázce po smyslu vzdělávání (Biesta, 2009) a poskytovat vzdělávání pro budoucnost, které se pak logicky nemůže spoléhat na výuku faktů, protože o budoucnosti se zatím neobjeví žádná fakta, ale bude zdůrazňovat rozvoj kompetencí, které poskytnou generacím mladých lidí možnost vytvářet takovou budoucnost, jakou chtějí. Tím ovšem nechceme říci, že neexistuje žádné úsilí o zpochybnění současného stavu: existuje mnoho inspirativních pedagogických hnutí a přistupů, ředitelů škol a hlavně učitelů, kteří se věnují vytváření smysluplných zážitků z učení, které se věnují rozvoji celého dítěte a vnímají své žáky nejen jako budoucí pracovní sílu, a tento článek popisuje práci některých z těchto inspirativních učitelů.

Článek zkoumá význam konceptu, který nazýváme Vzdělávání pro budoucnost (VpB), tedy pedagogiky, která u mladých lidí rozvíjí představivost, posiluje jejich postavení (empowerment) a zapojuje je do vytváření budoucnosti. Zabývá se cíli vzdělávání popsanými v kapitole 1.4 dokumentu ČR 2030: Vzdělávání rozvíjí individuální potenciál jedinců a jejich schopnost zvládat i ovlivňovat změny a podporuje soudržnou společnost orientovanou na udržitelný rozvoj (Úřad vlády České republiky, 2015). Model Vzdělávání pro budoucnost vychází z Klíčových kompetencí pro udržitelnost (Reickmann, 2017), Akční kompetence (Jensen a Schnack, 1997) a Kreativních návyků mysli (Lucas et al., 2013) rozvíjených pomocí kreativního vzdělávání (interdisciplinární, participativní a zážitková výuka využívající umění a kreativní profese) a vybavuje žáky kompetencemi, které budou potřebovat pro zvládání náročných výzev 21. století, jako je "zvyšující se komplexnost a nejistota, rostoucí individualizace a společenská diverzita, větší ekonomická a kulturní uniformita, zhoršující se ekosystémové služby, na kterých společnost závisí, a zvýšená zranitelnost a vystavení přírodním a technologickým hrozbám." (Rieckmann, in Leicht et al., 2018). Projekt je také reakcí na rozvoj klíčových kompetencí popsaných v EVVO: "Vztah k př́rodě" a "Vztah k místu". Navrátil (2012) popisuje význam tvưrčí práce $v$ prírodě pro podporu rozvoje těchto klíčových kompetencí. Model VpB byl představen v pilotním projektu stejného názvu ve čtyřech třídách (1.-9. třída) v období 2019-2021. Na projektu spolupracovalo Oddělení environmentálního vzdělávání Centra pro otázky životního prostředí, které se zaměřuje na rozvoj kompetencí udržitelnosti, a Společnost pro kreativitu ve vzdělávání, která již 10 let implementuje projekty kreativního vzdělávání na školách v celé České republice.

\section{Definice problému}

Globální politická iniciativa nazvaná Dekáda OSN vzdělávání pro udržitelný rozvoj (UNDESD) byla reakcí na potřebu transformace vzdělávání. Měla za cíl transformovat vzdělávací systémy, což by následně vedlo ke společenské změně, kýženého cíle ale nedosáhla (Huckle \& Wals, 2015) a my vidíme minimálně čtyři faktory, které přispívají k neúspěchu:

\footnotetext{
${ }^{1}$ Neoliberální předpoklad: "Zaprvé je to představa o jednotlivci sledujícím vlastní zájem, kdy se předpokládá, že jednotlivci nejlépe posuzují svůj prospěch a potřeby. Jednotlivci sledující vlastní prospěch se následně stávají aktéry na trhu, který definuje tržní ekonomika... ta je považována za nejefektivnější mechanismus přidělování zdrojů a př́ležitostí. Zásadní význam jednotlivce a volného trhu vede k neskrývanému omezování státní/vládní kontroly s výjimkou ochrany práv jednotlivce. Posledním předpokladem je oddanost volnému trhu, která zahrnuje odstranění všech forem státem uvalené ochrany či podpory, aby byly zaručeny optimální podmínky pro jednotlivce a trh." (Olssen and Peters, 2005, str. 314-315, ve Hunter et al., 2018)
} 
1. Ekologické vzdělávání se i nadále vede v duchu scientismu, který neumožňuje žákům pochopit sociální a společenské souvislosti hlavních přičin environmentálních problémů a uvědomit si „možnosti konat" vlastní jednotlivcům i společnosti (Jensen \& Schnack, 1997).

2. Může být nedostatečné pochopení způsobu, jakým se budoucnost "přihodí", že budoucnost můžeme do určité míry aktivně změnit a tvořit. Analýza odborníka na studia budoucnosti Noela Gougha (1990) ukazuje, že uvažování o budoucnosti se ve vzdělávání objevuje jedním z následujících způsobů:

- jako nevyslovený předpoklad: o budoucnosti se nebavíme, ale předpokládáme, že se prostě sama objeví;

- jako schematické zmínky: o budoucnosti mluvíme skrze stereotypní představy a klišé, ale ty mají jen málo skutečného podrobně promyšleného obsahu; jako neochvějná přesvědčení: bavíme se o budoucnosti nebo o několika možných alternativních budoucnostech, jako by šlo o samožrejmost, jako by jiné možnosti neexistovaly.

3. Vzdělávání pro udržitelnost často vychází z transmisivních modelů vzdělávání. Je však třeba přejít k participativním, socio-konstruktivistickým, transformativním modelům (Wals a Jickling v Corcoran a Osano, 2009), protože je třeba změnit neudržitelné jednání jednotlivců a celé společnosti. Vzdělávání pro udržitelnost proto musí vycházet z konstruktivistické teorie a zapojit žáky do učení formou spolupráce a kooperace (Jenkins, 2015).

4. Vzdělávání čelí ještě dalšímu problému, a sice že dominantní západní kultura oceňuje racionálně-kognitivní způsoby vědění, ačkoliv mnoho z kompetencí, které potřebujeme, abychom dokázali čelit problémům 21. století, se nachází mimo kognitivní oblast, především v oblasti afektivní (UNESCO, 2017). Kollmuss a Agyeman (2002) detailně popisují propast mezi věděním a jednáním a tvrdí, že pro vytvoření „proekologického vědomí je zásadní emoční účast. Při pedagogickém působení $v$ afektivní oblasti je samozřejmě třeba mít na paměti možné zneužití postupů sociálně-emocionálního učení k manipulaci žáků namísto toho, aby je učitelé podporovali $v$ samostatném projevu (používání jejich hlasu), a také předcházet rizikům zneužití neregulovaných negativních emocí.

Model VpB tyto problémy řeší pomocí metod vycházejících ze čtyř základních konceptů: 1) Akční kompetence (Jensen a Schnack, 1997) a Lundyové model participace (2007); 2) Uvažování o možných budoucnostech; 3) Klíčové kompetence pro udržitelnost (Reichmann, 2017); 4) Kreativní učení se (interdisciplinární pedagogika se zapojením umění) pro práci s afektivní doménou. Nyní tyto čtyři oblasti probereme.

\section{Akční kompetence}

Akční kompetence (Jensen a Schnack, 1997) nám může posloužit jako užitečný výchozí rámec při zkoumání cest vedoucích $\mathrm{k}$ transformativnímu učení tím, že dětem nabídnou přiležitosti zapojit se do fungování komunit. Autoři popisují čtyři základní složky akční kompetence:

- Znalost a vhled: Rozvoj znalosti témat sociální, environmentální a ekonomické udržitelnosti a možných řešení těchto problémů. Jensen a Schnack zdůrazňují, že znalosti jsou jen jednou částí akční kompetence.

- Zapojení se: Rozvíjení odhodlání k akci. Klíčovou součástí je zapojení žáků do rozhodovacích procesü a možnost být aktivními občany.

- Vize: Kreativní uvažování nad tím, jak mohou žáci sami přispět k lepšímu světu.

- Akční zkušenosti: Účast žáků na projektech, které se zaměřují na řešení konkrétních problémů nebo jsou koncipovány na základě určitých výsledků. Akčnost (action-taking) zde znamená dobře uvážený a úmyslný proces, který přesahuje pouhou "aktivitu" či "zkušenost". 
Tyto akční zkušenosti mohou být príležitostí pro emočně nabité učení se, zvlášt' pokud je účast kolektivní a vyžaduje spolupráci.

Při popisu schopnosti, kterou jsme u žáků chtěli podporovat - jejich sebepojetí jako aktérů změny - jsme vycházeli z modelu akční kompetence. Model, který nám pomáhal rozvíjet akční kompetenci, především Zapojení se, a sebepojetí žáků jako aktérů změny, je Lundyové model participace (2007), který vychází z Úmluvy OSN o právech dítěte z roku 1990. Úmluva vytvořila důležitý prostor pro rozvoj konceptu "hlasu dítěte", který se explicitně objevuje v článku 12 Úmluvy:

Státy, které jsou smluvní stranou úmluvy, zaručují dítěti schopnému formulovat své vlastní názory právo tyto názory svobodně vyjadřovat ve všech záležitostech, které se jej dotýkají, príčemž se názorům dítěte musí věnovat patřičná pozornost odpovídající jeho věku a úrovni.

Obrázek 1. Lundyové model participace, (Lundy, 2007)

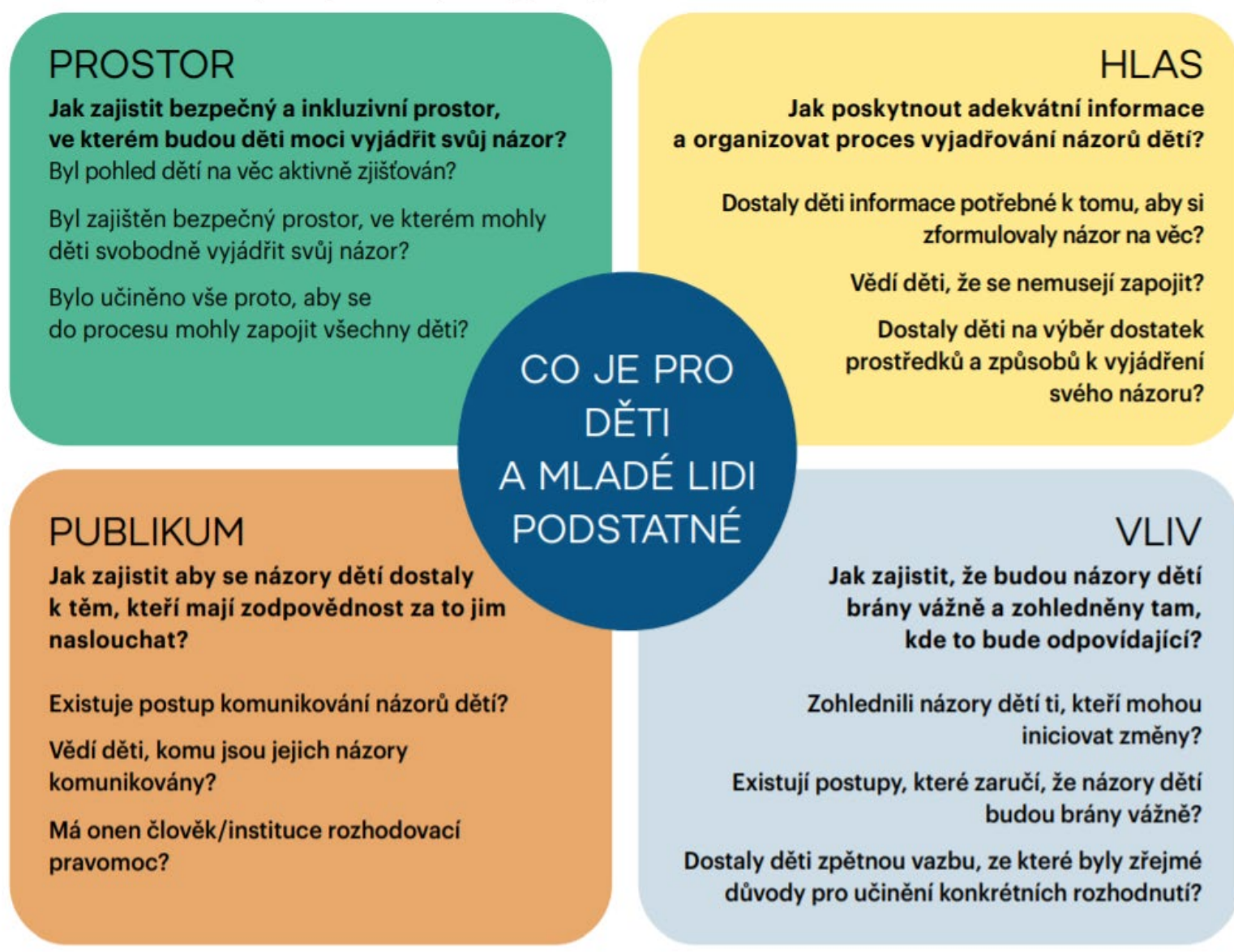

Na základě článku 12 vytvořila Laura Lundy (Lundy, 2007) model dětské participace. Je to konceptuální nástroj, který má pomoci zajistit dítěti právo na to, aby jeho názory byly brány $\mathrm{v}$ potaz ve všech otázkách, které se ho v rámci vzdělávání dotýkají. Model má za úkol pomoci osobám s rozhodovací pravomocí pochopit hlavní body článku 12: prostor (přiležitost formovat a vyjadřovat své názory), hlas (možnost vyjadřovat názory), posluchači (tyto názory je třeba vyslechnout), vliv (názory dítěte by měly vyvolat patřičnou reakci). Model byl přijat v rámci Národní strategie Irska pro participaci dětí a mládeže v rozhodovacích procesech 2015-2020. Během implementace se model snaží rozvíjet schopnost dětí vnímat se jako osoby, které mají možnost jednat a mají názor, jež může ovlivňovat situace, které se jich dotýkají. 


\section{Uvažování o verzích budoucnosti}

Pevnou součástí vzdělávání pro udržitelnost musí být otázka po tom, jak by mohla/měla vypadat budoucnost a jakou máme odpovědnost vưči budoucím generacím. Tato otázka má praktické dopady na pedagogiku. Různé skupiny lidí mají různé představy o „lepší budoucnosti” a pedagogické přistupy pro udržitelnost a pro umění poskytují prostor, kde mohou různorodé zúčastněné strany zkoumat minulost i prítomnost a představovat si budoucnost. Futurologie (Futures Studies) ve své typologii možných orientací na budoucnost rozlišuje budoucnost pravděpodobnou, možnou, preferovanou a výhledovou (Gidley et al., 2004). Identifikuje a analyzuje tak základní paradigmata, která ovlivňují, jak o budoucnosti uvažujeme a jak se stavíme k pedagogickým př́stupům, které by mohly dát mladým lidem možnost vytvářet budoucnost takovou, jakou si přejí. Více o tomto konceptu v souvisejícím článku Henderson a Dlouhá (2021).

\section{Klíčové kompetence pro udržitelnost}

Dokumenty globální, evropské i národní vzdělávací politiky nabádají k transformaci vzdělávání směrem k celoškolním př́stupům zaměřeným na kompetence (OECD, 2018; UNECE, 2012; UNESCO, 2014; UNESCO, 2017; Úřad vlády České republiky, 2015), vzdělávací normy po celém světě i v ČR však jdou proti této změně tím, že dále upevňuji kurikula založená na jednotlivých předmětech, která se více zabývají získáváním vědomostí než rozvojem kompetencí.

Projekt se zaměřoval na šest z osmi klíčových kompetencí pro udržitelnost popsaných Rieckmannem $(2017)^{2}$. Jejich seznam najdete $v$ Tabulce 1 dále.

Dnes již chápeme, že kognice není důsledkem pouze mentálních procesů: výzkumy v oblasti neurobiologie ukazují, že kognitivní aspekty, které ve škole používáme nejvíce, jsou ovlivněny emočními procesy a jsou jejich součástí. Jsou nezbytné $\mathrm{k}$ tomu, abychom dovednosti a vědomosti, které získáme ve škole, dokázali převést do nových situací a skutečného života (Immordino-Yang a Damasio, 2007, Dlouhá et al, 2020). Pokud chceme rozvíjet širokou škálu kompetencí pro udržitelnost, musíme přemýšlet, jak co nejlépe stimulovat kognitivní i afektivní doménu.

2 Důvodem pro tento výběr bylo to, že strategické kompetence a kompetence $k$ integrovanému řešení problémů jsou $v$ afektivní doméně méně aktivní. 
Tabulka 1. Klíčové kompetence pro udržitelnost, Rieckmann, M. (2017), Education for sustainable development goals: Learning objectives. UNESCO Publishing (Cíle vzdělávání pro udržitelný rozvoj: Cíle učení)

\begin{tabular}{|c|c|}
\hline $\begin{array}{l}\text { Kompetence } \\
\text { k systémovému } \\
\text { myšlení: }\end{array}$ & $\begin{array}{l}\text { schopnosti rozpoznat a chápat vztahy; analyzovat komplexní systémy; přemýš- } \\
\text { let o tom, jak jsou systémy zasazeny v různých doménách a nabývají různých } \\
\text { měřítek; pracovat s nejistotou. }\end{array}$ \\
\hline $\begin{array}{l}\text { Kompetence } \\
\text { k anticipačnímu } \\
\text { myšlení: }\end{array}$ & $\begin{array}{l}\text { schopnosti pochopit a vyhodnotit rưzné budoucnosti - možné, pravděpodobné } \\
\text { a žádoucí; vytvářet vlastní vize budoucnosti; používat princip prevence; zvážit } \\
\text { dopady jednání; pracovat s riziky a změnami. }\end{array}$ \\
\hline $\begin{array}{l}\text { Normativní } \\
\text { kompetence: }\end{array}$ & $\begin{array}{l}\text { schopnosti chápat a reflektovat normy a hodnoty, které člověka vedou k jed- } \\
\text { nání; jednat o hodnotách, principech, cílech a záměrech udržitelnosti v kon- } \\
\text { textu konfliktu zájmů a kompromisů, nejistých znalostí a rozporů. }\end{array}$ \\
\hline $\begin{array}{l}\text { Kompetence ke } \\
\text { spolupráci: }\end{array}$ & $\begin{array}{l}\text { schopnosti učit se od ostatních; chápat a respektovat potřeby, hlediska a jed- } \\
\text { nání ostatních (empatie); chápat, vztahovat se a být citlivý k druhým (empa- } \\
\text { tické vedení); řešit konflikty ve skupině; podporovat spolupráci a participativní } \\
\text { rešení problémů. }\end{array}$ \\
\hline $\begin{array}{l}\text { Kompetence ke } \\
\text { kritickému myš- } \\
\text { lení: }\end{array}$ & $\begin{array}{l}\text { schopnost zpochybňovat normy, postupy a názory; reflektovat vlastní hod- } \\
\text { noty, pohledy a jednání; zaujmout vlastní postoj v rámci diskurzu udržitel- } \\
\text { nosti. }\end{array}$ \\
\hline $\begin{array}{l}\text { Kompetence } \\
\text { k sebe-uvědo- } \\
\text { mění: }\end{array}$ & $\begin{array}{l}\text { schopnost reflektovat vlastní roli v místní komunitě a (globální) společnosti; } \\
\text { průběžně hodnotit a dále motivovat své činy; zabývat se svými pocity a tou- } \\
\text { hami. }\end{array}$ \\
\hline
\end{tabular}

Analýza kompetencí k udržitelnosti zkoumá rozložení aspektů těchto kompetencí v rámci kognitivní a afektivní domény na základě analýzy Dlouhá, Henderson et al., (2019, 2020), jak ukazuje Tabulka 2. 
Tabulka 2. Rozložení aspektů kompetencí v kognitivní a afektivní doméně (podle Dlouhá, Henderson et al., 2019, Dlouhá at al., 2020).

\begin{tabular}{|c|c|}
\hline $\begin{array}{l}\text { Doména } \\
\text { učení se }\end{array}$ & Kompetence VUR, UNESCO 2017 \\
\hline $\begin{array}{l}\text { Kognitivní } \\
\text { doména }\end{array}$ & $\begin{array}{l}\text { Kompetence systémového myšlení: rozpoznat a pochopit vztahy; analyzovat } \\
\text { komplexní systémy; přemýšlet o tom, jak systémy souvisejí mezi sebou a nabývají } \\
\text { různých měŕítek } \\
\text { Anticipační kompetence: pochopit a dokázat vyhodnotit různé budoucnosti } \\
\text { Normativní kompetence: pochopit a reflektovat hodnoty v kontextu konfliktů zá- } \\
\text { jmů a kompromisů, nejistých znalostí a protikladů } \\
\text { Kompetence spolupráce: kolektivně rozvíjet a zavádět inovativní řešení, a to } \\
\text { na místní úrovni a mimo ni } \\
\text { Kompetence kritického myšlení: zpochybňovat praxi a názory v kontextu střetu } \\
\text { zájmů a kompromisů, nejistých znalostí a rozporů }\end{array}$ \\
\hline $\begin{array}{l}\text { Afektivní } \\
\text { doména }\end{array}$ & $\begin{array}{l}\text { Kompetence systémového myšlení: pracovat s nejistotou } \\
\text { Anticipační kompetence: vytvářet vlastní vize do budoucna } \\
\text { Normativní kompetence: porozumět normám a hodnotám, které jsou základem } \\
\text { jednání, vyjednat hodnoty udržitelnosti, zásady a cíle } \\
\text { Kompetence spolupráce: zabývat se konflikty ve skupině; rozumět, učit se od } \\
\text { ostatních, porozumět a respektovat potřeby, perspektivy a činy druhých (empatie); } \\
\text { vztahovat se a být citlivý vưči ostatním (empatické vedení); podporovat spolupráci a } \\
\text { participativní řešení problémů; kolektivně vytvářet a zavádět inovativní akce, které } \\
\text { rozvíjejí udržitelnost } \\
\text { Kompetence kritického myšlení: zpochybňovat normy, reflektovat vlastní hod- } \\
\text { noty, názory a činy } \\
\text { Kompetence sebe-uvědomění: přemýšlet o vlastní roli v místní komunitě a glo- } \\
\text { bální společnosti; umět se vypořádat se svými individuálními pocity a touhami; prů- } \\
\text { běžně hodnotit a dále motivovat své činy }\end{array}$ \\
\hline
\end{tabular}

Tabulka ilustruje, jak důležité je vytvořit pedagogické přístupy, které věnují pozornost afektivní doméně, pokud usilujeme o rozvinutí všech aspektů kompetencí pro udržitelnost.

Dlouhá et al. (2020) popisují normativní a transformativní dimenzi rozvoje kompetencí pro udržitelnost. Normativní dimenze popisuje instrumentální učení se $v$ rámci kognitivních domén, jež nevyžaduje velkou osobní angažovanost a reflexi hodnot, směřující k hlubší normativní rovině přes konativní, sociální až po emocionální doménu. Transformativní dimenze odráží postup od holistického porozumění přes vytváření vize změny $k$ docílení transformace. Tyto tři kategorie "vyznačují vývoj směrem ke kýžené budoucnosti... holistický př́stup a myšlení orientované na budoucnost jsou podmínkami transformace" (Dlouhá et.al 2020).

\section{Kreativní vzdělávání/učení a afektivní doména}

Při hledání pedagogického př́stupu, který by aktivoval kognitivní i afektivní doménu, se můžeme opřit o velký objem výzkumu, který zkoumá roli kreativní učení $v$ podpoře učení ve $v$ obou doménách (Bradley a Szegda, 2006; Schmirrmacher, 2002; Welch, 2006, v Gadsden, 2008; Blumenfeld, Kempler, \& Krajcik, 2005; Catterall \& Waldorf, 1999; Dewey, 2005; Efland, 2002; Greene, 
1995; Hetland \& Winner, 2001; Marshall, 2005; Ofsted, 2006; Scripp, \& Yung-Chin Paradis, 2013; Winner, Goldstein, \& Vincent-Lancrin, 2013; Everett et al. 2015; Hunter et al. 2018).

Pro upřesnění, $v$ tomto článku chápeme kreativní vzdělávání jako proces probíhající na systémové úrovni v kontextu formálního vzdělávacího prostředí, zatímco kreativní učení popisuje interný proces na individuální úrovni. Kreativní učení jako proces může mít různé formy, může zapojovat vyučující umělce (profesionální umělce, kteří přicházejí z prostředí mimo školu), učitele uměleckých předmětů ve spolupráci s ostatními učiteli, nebo ho mohou používat samotní učitelé bez podpory profesionálních umělců a učitelů uměleckých předmětů. Kreativní vzdělávání podle definice, která vyplývá z britského kontextu ${ }^{3}$ a se kterou pracují organizace zastřešené platformou uMĚNíM ${ }^{4}$, pracuje s pojetím, které ho chápe jako vzdělávání, v němž umění a kulturní aktivity vědomě cílí k rozvoji kognitivních, sociálních a emočních schopností. Přispívá k rozvoji dovedností mladých lidí v oblasti spolupráce, rozhodování i kritického přemýšlení o světě. Podporuje je v uvažování o jiných alternativách života $v$ budoucnosti, kterou mohou aktivně spoluvytvářet.

Kreativní vzdělávání zahrnuje:

- Vzdělávání uměním, tedy vzdělávání s využitím možností a technik uměleckých oborů a kreativních průmyslů,

- kreativní učení, tedy rozvoj kreativního myšlení dětí, žáků a mladých lidí, rozvoj inovativních přístupů k učení a učení se s využitím umění, kulturních aktivit a kreativních postupů,

- Vzdělávání k umění, tedy rozvoj znalostí, dovedností a technik, které vedou ke poznáni daného uměleckého oboru.

Učení se pomocí umění a umělecké tvorby (at́ už se jedná o jednooborový př́stup nebo v kontextu mezioborového kreativního učení se) v různé míre reorganizuje nervová spojení a mozkové funkce a díky tomu ovlivňuje způsoby a rozsah schopností mozku zvládat další úkoly (Catterall, 2005 v Burnaford, 2007). Dále bylo vysledováno, že kreativní učení má pozitivní vliv na

- Klima ve třídě a ve škole a na zapojení žáků (Catterall \& Waldorf, 1999 v Burnaford, 2007),

- na vytrvalost, pozornost, motivaci, spolupráci a řešení problémů (Imms at al., 2011; DeMoss a Morris, 2002; Rostan, 2010; Mason et al., 2008),

- na sebekázeň, self-efficacy (vědomí vlastní účinnosti), empatii, lepší pochopení dopadů vlastního chování, zpochybňování domněnek a stereotypů, schopnost zvládat nejednoznačnosti, na flexibilitu (Ewing, 2011), schopnost představit si různé možnosti (Gullat, 2008),

- na zvýšenou sebedůvěru a ochotu podstupovat pozitivní riziko (Hefferen, 2005 v Burnaford, 2007; Wright et al. 2006; Respress a Lufti, 2006) a

- na vnímání osobní a sociální identity (Winner et al 2006; Chemi a Du 2017).

Strategie spolupráce $z$ oblasti kreativního tance, hudby, vizuálních umění a divadelních aktivit mají za následek prokazatelný nárůst v mozkové synchronii a s ní souvisejícím vytváření vztahů. Tato spolupráce podporuje odbourávání starých vzorců chování (Freeman, 1995 in Ewing, 2011). A nakonec to, co je pro naše zkoumání aktivního občanství a Akční kompetence obzvlášt zajímavé, vystavení kreativnímu vzdělávání vede k většímu zapojení žáků do komunitních služeb (tamtéž) a $\mathrm{k}$ jejich větší participaci v politice (Catterall, 2009).

\footnotetext{
${ }^{3}$ Culture Creativity and Education https://www.creativitycultureeducation.org/

${ }^{4}$ uMĚNÍM Platforma pro kreativní učení https://www.facebook.com/platformaumenim
} 
UNESCO (2010) uznává zásadní roli, kterou kreativní vzdělávání hraje ve vzdělávacích reformách a při transformaci vzdělávacích systémů, jež jsou základem pro udržitelnou společnost. Jedním $z$ největších dilemat $v$ transformaci vzdělávání je vzájemně nesouvisející souhrn vědomostí a způsobů vědění (Hunter a kol. 2018, str. 28) v kurikulu, které nedokáže zohlednit komplexnost současné společnosti a problémy udržitelnosti. Jak nás může umění v kontextu kreativního učení zaujmout jako jednotlivce a pomáhat nám jednat kolektivně ve jménu udržitelnosti? Anděl předkládá dvě cesty:

Umění vybízí k účasti, a tak překonává rozdíl mezi sledováním a děláním „umění", podněcuje mezioborovou spolupráci, protože překonává hranice specializovaných oborů snadněji než jiné lidské aktivity (Anděl 2015).

Kreativní učení spojuje emoční stránku s kognitivní; zapojuje srdce i mysl a poskytuje dětem príležitost zkoumat témata, řešit problémy, spolupracovat a rozvíjet svoje nápady během tvoření (Everett et al., 2009 str. 180, ve Hunter et al. 2018, str. 29). Při kreativní činnosti vzniká prostor, kde je možné "setkávat se s neznámým a nepředstavitelným, prostor, který učí tolik potřebné pokoře nevědění" (Chaudhuri ve Hunter et al., 2018 str. 77). Tento proces nám pomáhá přijmout fakt, že budoucnost je nestabilní a nejistá, protože o ní nemáme kompletní informace. Kreativní proces vytváření uměleckého díla - počínající v představivosti a pokračující plánováním, změnami a kritickou reflexí v průběhu tvoření - zrcadlí proces představování si a vytváření budoucnosti jako takové (Hunter et al., 2018, str.78).

Pro náš model Vzdělávání pro budoucnost jsou důležité zejména následující body z práce Hunterové et al. (2018) na téma propojení vzdělávání pro udržitelnost a kreativního učení: Ve vzdělávání pro udržitelnost jde především o zaznamenání a pochopení změny, zatímco $v$ kreativním učení jde o zakoušení, materializování, ztělesňování a v určitých kontextech i komunikování změny. Udržitelnost i umění ve výuce mají žáky přimět jednat (Hunter et al., 2018).

- Kvalitní kreativní vzdělávání obsahuje mnoho principů a postupů vzdělávání pro udržitelnost, které žákům umožní zakoušet nejistotu, aktivní jednání a změny. Propojování uměleckého vzdělávání a vzdělávání pro udržitelnost umožňuje, aby se žáci afektivně i kognitivně zapojovali do konceptů a zkušeností se proměna (tamtéž).

Hunter et al. (2018) odkazují na model estetického vzdělávání (Abbs, 1989), v němž procesy tvorby, prezentace, reakce a transformace popisuji zkušenostní dimenze kreativní učení:

„Procesy tvorby a prezentace odkazují na záměr a praktickou stránku umění. Při procesech reakce a transformace žáci kriticky a kreativně analyzují a hodnotí vlastní umění nebo umění ostatních... K transformaci dochází, když žáci zaznamenají a přiznají si změnu svého porozumění jako průvodní jev nebo následek své zkušenosti s procesem tvorby, prezentace a reakce." (Hunter et al., 2018 str. 27).

Tento model odráží Freireův (1970) model praxe pro emancipační vzdělávání (kombinující jednání a reflexi) a dále ilustruje, jak může kreativní učení přispět k osobní transformaci, která je zásadní pro kompetence pro udržitelnost.

\section{Kreativní návyky mysli}

Model Kreativní návyky mysli (Lucas, Claxton, \& Spencer, 2013) popisuje specifické kompetence rozvíjené kreativním učením. Používal se v rámci programu Kreativních partnerství při spolupráci mezi umělcem a učitelem libovolného předmětu jakožto nástroj pro posílení uvědomění si a pochopení kreativity mezi učiteli a žáky a také jako nástroj pro vyhodnocování pokroku v kreativitě, viz Obrázek 2 dále. 
Obrázek 2. Model kreativních návyků mysli, in Lucas, B., Claxton, G., \& Spencer, E. (2013) (překlad a vizuální zpracováni, Společnost pro kreativitu ve vzdělávání)

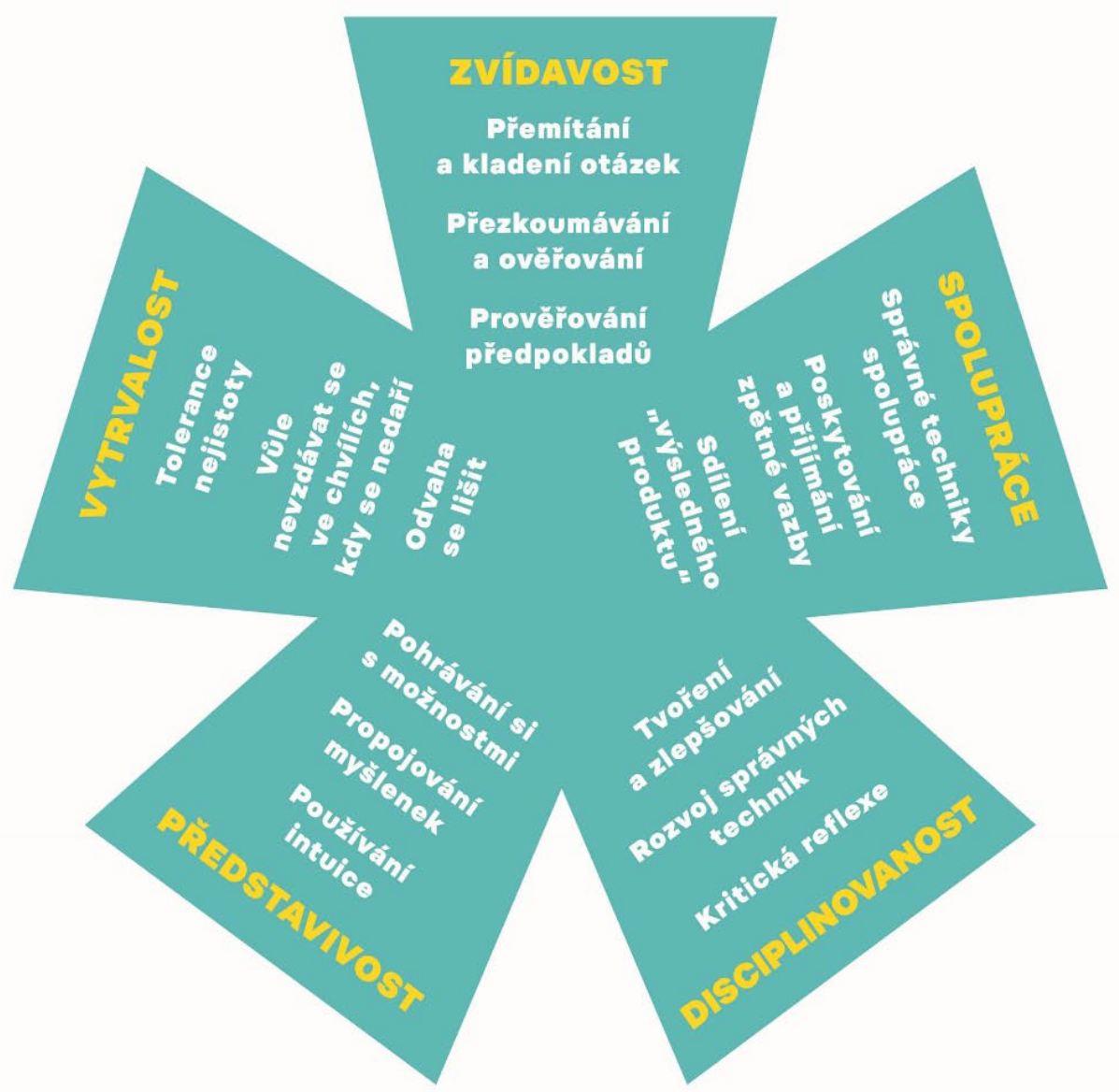

Kreativní návyky mysli byly rozděleny do různých kognitivních a afektivních domén, jak ilustruje tabulka 3, na základě práce Blooma, Krathwohla a Masiy (1973) o afektivní doméně a dále podle Andersonova a Krathwohlova (2001) přepracování Bloomovy práce o kognitivní doméně (1956). 
Tabulka 3. Distribuce kreativních návyků mysli ((Lucas, Claxton, \& Spencer, 2013) v rámci kognitivních a afektivních domén učení (tučně je vyznačeno pět hlavních aspektů), (navrženo autory).

\begin{tabular}{|l|l|}
\hline $\begin{array}{l}\text { Kognitivní } \\
\text { doména }\end{array}$ & $\begin{array}{l}\text { Představivost } \\
\text { Propojování myšlenek } \\
\text { Pohrávání si s možnostmi } \\
\text { Zvídavost } \\
\text { Přemítání a kladení otázek } \\
\text { Přezkoumávaní a ověřování } \\
\text { Disciplinovanost } \\
\text { Kritická reflexe }\end{array}$ \\
\hline $\begin{array}{l}\text { Afektivní } \\
\text { doména }\end{array}$ & $\begin{array}{l}\text { Představivost } \\
\text { Pohrávání si s možnostmi } \\
\text { Použivání intuice } \\
\text { Zvídavost } \\
\text { Prověrování předpokladů } \\
\text { Vytrvalost } \\
\text { Odvaha se lišit } \\
\text { Vůle nevzdávat se ve chvílích, kdy se nedaří } \\
\text { Toleruje nejistoty } \\
\text { Disciplinovanost } \\
\text { Kritická reflexe } \\
\text { Spolupráce } \\
\text { Poskytování a přijímání zpětné vazby } \\
\text { Správné techniky spolupráce } \\
\text { Sdílení „výsledného produktu" }\end{array}$ \\
\hline
\end{tabular}

V následující kapitole přistoupíme $\mathrm{k}$ analýze kreativních návyků mysli podle jednotlivých domén učení se a spojení dvou výše popsaných modelů kompetence.

\section{Metoda: integrace VUR a kreativního učení. Model Vzdělávání pro bu- doucnost}

Naše analýza a zařazení klíčových kompetencí pro udržitelnost (Rieckmann, 2018) do kognitivních a afektivních domén učení se vychází z práce Dlouhé et al. (2019, 2020), kteří kodifikovali aspekty klíčových kompetencí pro udržitelnost do kognitivní, konativní, sociální a emocionální domény. Tato analýza je nicméně přizpůsobená rámci kompetencí pro udržitelnost UNECE (2011), jelikož jsme potřebovali rámec, který by dovolil zohlednit kreativní návyky mysli, jakož i klíčové kompetence pro udržitelnost. Rozhodli jsme se čerpat z práce Blooma, Krathwohla a Masiy (1973) v oblasti afektivní domény a z Andersonova a Krathwohlova (2001) přepracování Bloomovy (1956) práce $\checkmark$ oblasti kognitivní domény. 
Při vytváření systému pro porovnávání kompetencí pro udržitelnost a kreativních návyků mysli jsme se drželi transformativního rozměru Dlouhé et al. (2019), jelikož skýtá jasnou a potentní ilustraci toho, které kompetence a které domény učení slouží k rozvíjení akční kompetence a dosažení transformace. $V$ dalším kroku naší analýzy jsme potřebovali identifikovat model, s jehož pomocí bychom zařadili kreativní návyky mysli do převládajících domén učení: kognitivní a afektivní. Čerpali jsme z práce Blooma, Krathwohla a Masiy (1973) v oblasti afektivní domény a z Andersonova a Krathwohlova (2001) přepracování Bloomovy (1956) práce v oblasti kognitivní domény. Tyto detailní rámce jsme využili pro kodifikování aspektů kreativních návyků mysli ve vztahu k tomu, zda náleží primárně ke kognitivní, afektivní, či psychomotorické doméně. Tato poslední kategorie obsahovala pouze dva z patnácti kreativních návyků mysli (tvoření a zlepšování, rozvoj správných technik) a tyto nejsou zahrnuty do další analýzy (viz tabulka 4), jelikož se netýkají našeho tématu.

Výsledný nástroj, jejž používáme pro analýzu a srovnání kreativních návyků mysli a klíčových kompetencí pro udržitelnost, vychází právě z těchto tří výše popsaných zdrojů (Rieckmann, 2018; Dlouhá et al., 2019, Anderson and Krathwohl 2001). Náš analytický nástroj je jejich zjednodušenou verzí, nebot' detailnější analýza všech domén učení se není v rámci rozsahu projektu a tohoto článku možná. Slouží nicméně k prozkoumání a ilustraci toho, jak důležitá je socio-emocionální doména pro rozvoj kompetencí pro udržitelnost a role kreativního učení pro aktivaci této domény.

Tabulka níže poskytuje přehled aspektů charakteristik VUR (UNECE, 2012) a srovnává odpovídající aspekty Akční kompetence (Jensen \& Schnack, 1997), odpovídající kompetence pro VUR vycházející z UNESCO, (2017) a kreativní návyky mysli (Lucas, Claxton, \& Spencer, 2013) v doméně učení se, v nichž tyto kompetence fungují: kognitivní a afektivní. Již výše jsme shledali, že integrace všech domén je zásadní, jelikož učení se v kognitivní doméně nerozvíjí, pokud není aktivní i socioemocionální doména. Rozdělení aspektů kreativních návyků mysli na dvě domény neznamená, že domény učení se fungují odděleně, nebo že by vůbec mohly fungovat odděleně, ale ukazuje nám, která doména je dominantní v př́padě té které kompetence. Určité aspekty kreativních návyků mysli můžeme považovat za aktivní $v$ obou doménách, a je to i zohledněno $v$ tabulce. Účelem této tabulky však není debata nad jejím dělením, ale snaha ukázat, o jak velký edukativní potenciál žáci přijdou, když ignorujeme afektivní doménu. Je zcela zřejmé, že dosažení transformace závisí na práci v afektivní doméně. $Z$ toho vychází i náš postoj: je třeba zajistit, aby výchova pro udržitelnost aktivovala afektivní doménu, a kreativní učení má potenciál být mocným pedagogickým nástrojem vedoucím k tomuto cíli. Kreativní návyky mysli se významně překrývají s kompetencemi pro VUR popsanými detailně v Tabulce č. 4. 
Tabulka 4. Analýza vztahů mezi klíčovými charakteristikami VUR, elementy akční kompetence, vybranými kompetencemi VUR a kreativními návyky mysli rozdělenými na kognitivní a afektivní doménu.

\begin{tabular}{|c|c|c|c|}
\hline $\begin{array}{l}\text { Charakteristika } \\
\text { VUR: }\end{array}$ & Holistické myšlení & $\begin{array}{l}\text { Vytváření vize budouc- } \\
\text { nosti }\end{array}$ & Dosažení transformace \\
\hline Akční kompetence: & Znalosti a vhled & Odhodlání a vize & Akční zážitek \\
\hline Kompetence UR: & $\begin{array}{l}\text { Kompetence systémo- } \\
\text { vého myšlení } \\
\text { Kompetence kritického } \\
\text { myšlení }\end{array}$ & $\begin{array}{l}\text { Schopnost předvídání } \\
\text { Normativní kompetence }\end{array}$ & $\begin{array}{l}\text { Schopnost sebe-uvědo- } \\
\text { mění } \\
\text { Kompetence spolupráce }\end{array}$ \\
\hline $\begin{array}{l}\text { Kreativní návyky } \\
\text { mysli } \\
\text { Kognitivní doména }\end{array}$ & $\begin{array}{l}\text { Disciplinovanost } \\
\text { Kritická reflexe } \\
\text { Zvídavost } \\
\text { Přemítání a kladení otá- } \\
\text { zek } \\
\text { Přezkoumávaní a ověřo- } \\
\text { vání } \\
\text { Propojování myšlenek }\end{array}$ & $\begin{array}{l}\text { Představivost } \\
\text { Pohrávání si s mož- } \\
\text { nostmi }\end{array}$ & \\
\hline $\begin{array}{l}\text { Kreativní návyky } \\
\text { mysli } \\
\text { Afektivní doména }\end{array}$ & $\begin{array}{l}\text { Prověřování předpokladů } \\
\text { Toleruje nejistoty } \\
\text { Poskytování a přijímání } \\
\text { zpětné vazby } \\
\text { Kritická reflexe }\end{array}$ & $\begin{array}{l}\text { Představivost } \\
\text { Pohrávání si s mož- } \\
\text { nostmi } \\
\text { Zvídavost } \\
\text { Prověřování předpo- } \\
\text { klado̊ }\end{array}$ & $\begin{array}{l}\text { Zvídavost } \\
\text { Spoluprace } \\
\text { Používání intuice } \\
\text { Správné techniky spolu- } \\
\text { práce } \\
\text { Sdílení „výsledného pro- } \\
\text { duktu" } \\
\text { Vytrvalost } \\
\text { Odvaha se lišit } \\
\text { vůle nevzdávat se ve } \\
\text { chvílích, kdy se nedaří }\end{array}$ \\
\hline
\end{tabular}




\section{Pilotní implementace projektu Vzdělávání pro budoucnost}

Ve všech třídách pracoval umělec spolu s učitelem a žáky a využíval model Kreativních partnerství, který vytvořil fond pro kreativní vzdělávání Culture, Creativity and Education ${ }^{5}$. Slovo partnerství je tu zásadní, protože tato metoda je participativní, podporuje žáky, aby projekt vedli spolu $\mathrm{s}$ učitelem a umělcem. Př́tomen je i konzultant kreativity, který zajišt́uje úvodní mapování třídy, výběr umělce, design projektu ve spolupráci s učitelem, žáky a umělcem, průběžná podpora, sledování cílů, závěrečná evaluace a hladkou komunikaci mezi vedením školy, učitelem a umělcem, a tím zajištúuje, že projekt probíhá v souladu s cíli projektu. Při plánování projektu se využíval model participace podle Lundyové (2007) tak, aby se využily př́ležitosti zapojit žáky do rozhodování v průběhu celého projektu.

Projekt VpB se vědomě snažil podpořit žáky, aby uvažovali nad tím, jak vzniká budoucnost, jak by mohla vypadat ( $v$ kontextu specifického tématu tříního projektu) a kdo je zodpovědný za to, aby budoucnost nastala. Participativní př́stup se explicitně soustředil na rozvoj sebepojetí žáků jako aktérů změny během realizace projektu - at' už ve třídě nebo na online výuce $z$ domova, $s$ cílem posílit tuto kapacitu pro život i mimo tř́du.

Učitelé a umělci zaznamenávali, jak žáci v průběhu celého projektu rozvíjejí své kompetence a vedením částečně strukturovaných rozhovorů s učiteli jsme zjišt́ovali jak vnímají svůj profesní rozvoj během projektu.

Níže poskytujeme krátký přehled čtyř třídních projektů, zaměřujeme se na specifické cíle, témata, interdisciplinární povahu projektů a na kompetence, které rozvíjely.

\section{Modř́nek}

Žáci první třídy poznávali své životní prostředí - městskou čtvrt' Modřany - a seznamovali se s problémy a výzvami udržitelného rozvoje, kterým Praha 12 čelí. Žáky projektem provázel kouzelný skř́tek Modřan, za kterým se vydávali na tematické vycházky po okolí školy. O tématu (např. voda, odpadky, ochrana prírody, doprava, vzduch) se více dozvídali přímo v terénu, plnili úkoly, společně hledali řešení. Ve škole žáci výtvarnými prostředky témata zpracovali a připravili podklady pro tematický pracovní sešit pro děti, který byl jedním z výstupů projektu.

$\checkmark$ projektu docházelo k propojení učiva předmětů český jazyk (abeceda, popis obrázku, příběh), člověk a jeho svět (bydliště, naše okolí, okolí školy, roční období, příroda), matematika (čísla, počítání) a výtvarná výchova. Žáci se s tématy udržitelnosti seznamovali skrze problémy životního prostředí Modřan, pracovali s recyklovanými materiály. Rozvíjeli také kompetence $\mathrm{k}$ udržitelnému rozvoji:

- Systémové myšlení (tok prírodních zdrojů a způsob, jakým se přeměňují na zboží, které Ize poté znovu použít a recyklovat).

- Kompetence sebe-uvědomění (přemýšlení o sobě samém a svém místě a roli v místní komunitě, městě, globální společnosti). Tato kompetence byla podpořena zejména kreativními návky mysli, jako je používání intuice: žáci byli vedeni k tomu, aby pozorovali a intuitivně se napojovali na místní přirozené prostředí a aby vyjadřovali tuto zkušenost a intuitivní formu kreativního vědění (viz níže). Zvídavost byla v tomto ohledu velmi důležitým kreativním návykem mysli. Žáci dostali př́ležitost zkoumat svou zvídavost v rámci prírody, ale byli vedeni i ke zvídavosti $v$ souvislosti $s$ emocemi, které během projektu pocitovali, a $v$ souvislosti $s$ tím, jak by se daly tyto emoce vyjádřit $v$ rámci uměleckého díla. Byli vedeni $k$ tomu, aby

${ }^{5}$ Culture, Creativity and Education https://www.creativitycultureeducation.org/ 
nakreslili své pocity frustrace nebo vzteku $v$ reakci na konflikty ve tř́dě a pocity radosti $a$ spojení na obrázcích jejich oblíbených aspektů přírody.
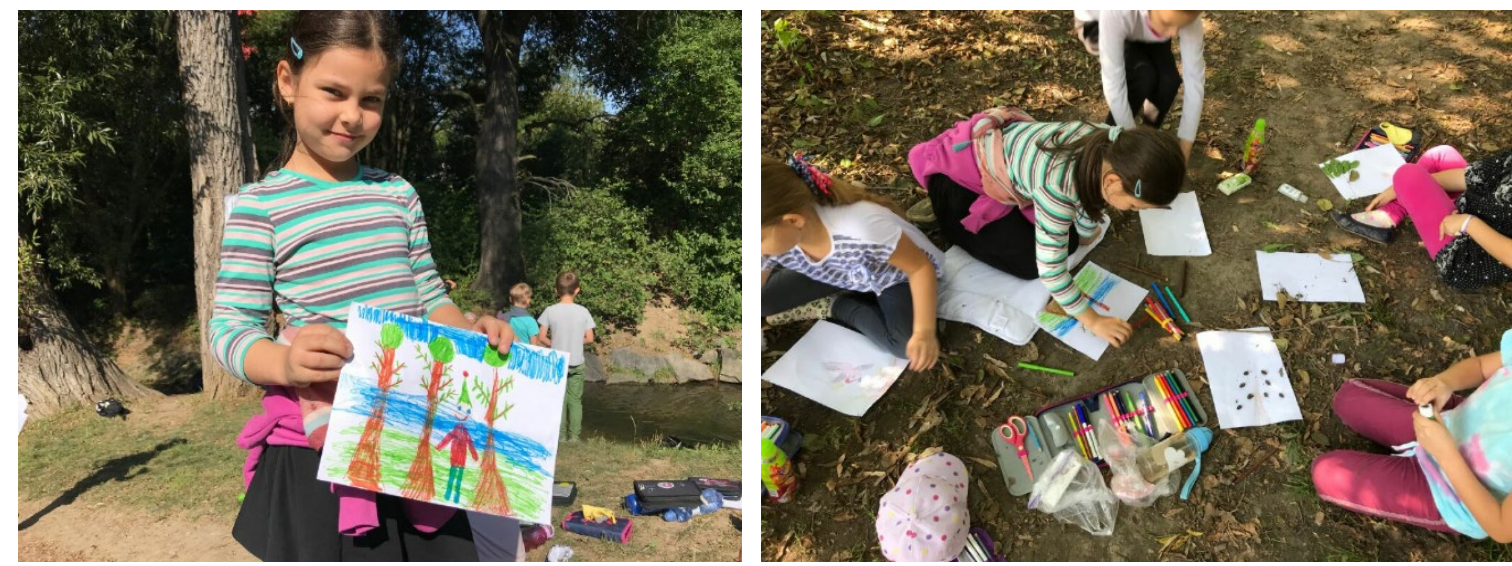

Žáci 2. třídy pozorují, malují a kreslí v prírodě, někteří do svých prací zapojují přírodní materiály.

- Normativní kompetence (žáci zkoumali, jak jsou normy a hodnoty základem lidského rozhodování a jednání: Co to znamená být př́telem? Jak si navzájem pomáháme a proč? Jak můžeme žít s úctou a péčí o prírodní svět a proč je to důležité?). Podrobné pozorování a kreativní práce $v$ prrírodě posílila pouto žáků $\mathrm{k}$ jejich lokálnímu přírodnímu světu, jak taky naznačuje Navrátil (2012).

- Kompetence spolupráce (jak rozumět a respektovat potřeby, perspektivy a jednání druhých (empatie), rozvíjení vztahů $\mathrm{k}$ druhým a být $\mathrm{k}$ nim citlivý (empatické vedení), rešení konfliktů ve skupině, spolupráce a participativní řešení problémů). Žáci pracovali $v$ malých skupinkách, tvořili a svou práci pak představili svým spolužákům (viz fotky níže):
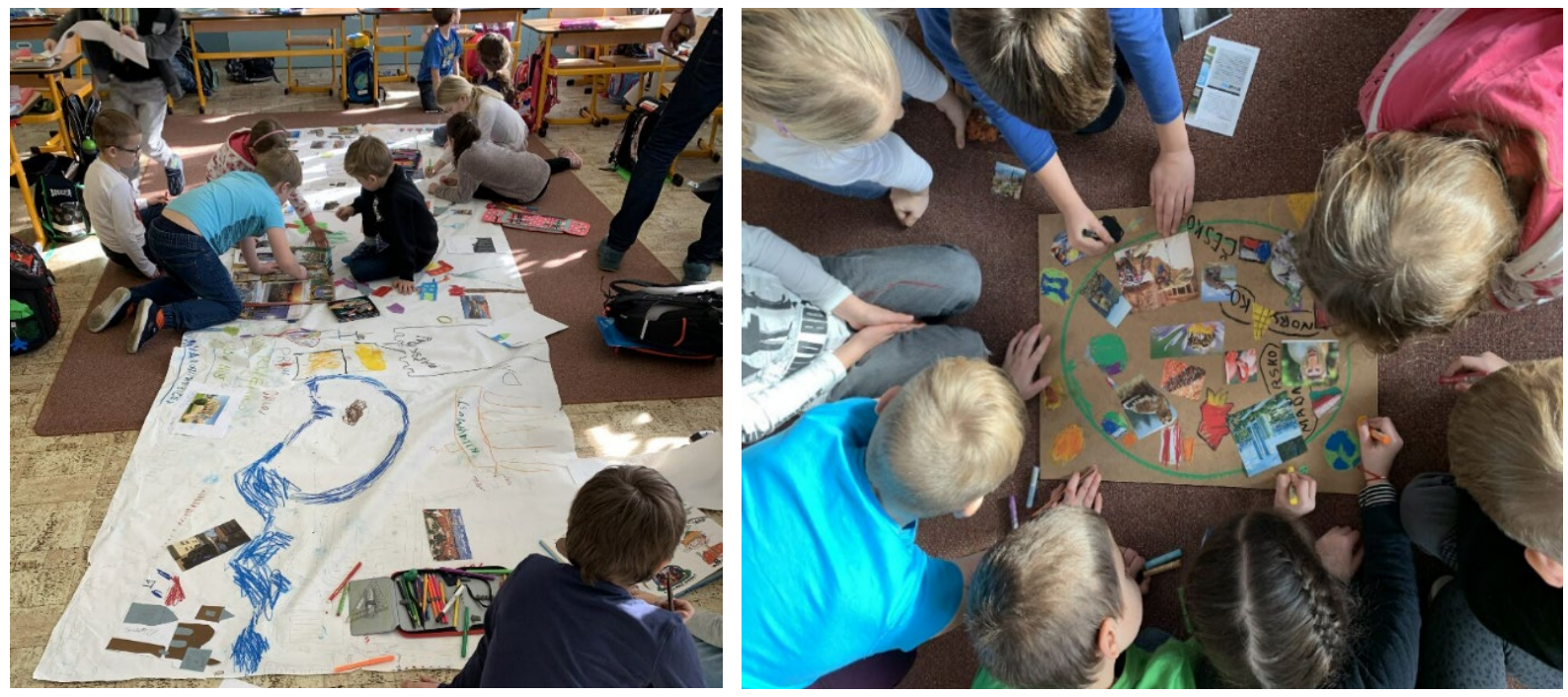

Žáci 2. tř́dy pracují na společném vytváření map (vlevo: celá tř́da vytváří mapu Prahy pomocí koláže a kresby, vpravo: malé skupinky vytvářejí mapy Evropy pomocí koláže).

\section{Město budoucnosti}

Žáci (7.třida) se zabývali konceptem Města budoucnosti v souladu s tématy udržitelného rozvoje. Diskutovali na téma město, ve kterém žijí a jak by mělo jejich ideální město vypadat. Realizovali průzkum veřejnosti. Jakým problémům Praha/naše čtvrt́ čelí? Co bych rád/ráda změnil/a? Jak si představuji danou lokalitu za 20 let? Žáci se seznamovali s tématy udržitelnosti a sami hledali řešení 
na problémy současnosti. Na základě práce $v$ terénu, rešerší a diskuzí navrhovali své vlastní Město budoucnosti, do kterého vnášeli inovativní řešení.

Žáci tvořili 3D model Města budoucnosti. Seznamovali se s různorodými výtvarnými technikami, včetně 3D skenování a základů tvorby prostředí počítačových her (concept art). Na závěr vznikla animace Město budoucnosti a video o projektu. Zábavným způsobem se seznamovali s geometrií, tématy urbanismu, architektury a řadou otázek $\mathrm{k}$ tématům udržitelného rozvoje. $\mathrm{V}$ projektu docházelo k propojení učiva výtvarné výchovy (skicování, kresba, modelování, různorodé výtvarné techniky), informačních a komunikačních technologií (práce s novými médii, concept art), matematiky (počítání, měření, geometrie), českého jazyka (popis), př́rodopisu (ekologie).

Zároveň projekt rozvíjel kompetence $\mathrm{k}$ udržitelnému rozvoji - žáci poznávali témata udržitelnosti v kontextu svého města/městské části a objevovali a zkoumali možná řešení problémů při návrzích a tvorbě modelu města budoucnosti. Projekt rozvíjel:

- Systémové myšlení: přemýšlení nad udržitelným využíváním přírodních zdrojů a obnovitelné energie ve vlastním městě, dopad specifické okolní krajiny na přístup k těmto zdrojům. Systémové myšlení bylo výrazně podpořeno vytvářením fyzického plánku a modelu města a okolní krajiny (viz fotky níže): když si žáci měli představit a navrhnout krajinu okolo svého města, uvědomili si hluboké propojení mezi konkrétními dostupnými prírodními zdroji a plánováním města. Původní plány pak na základě tohoto objevu měnili.
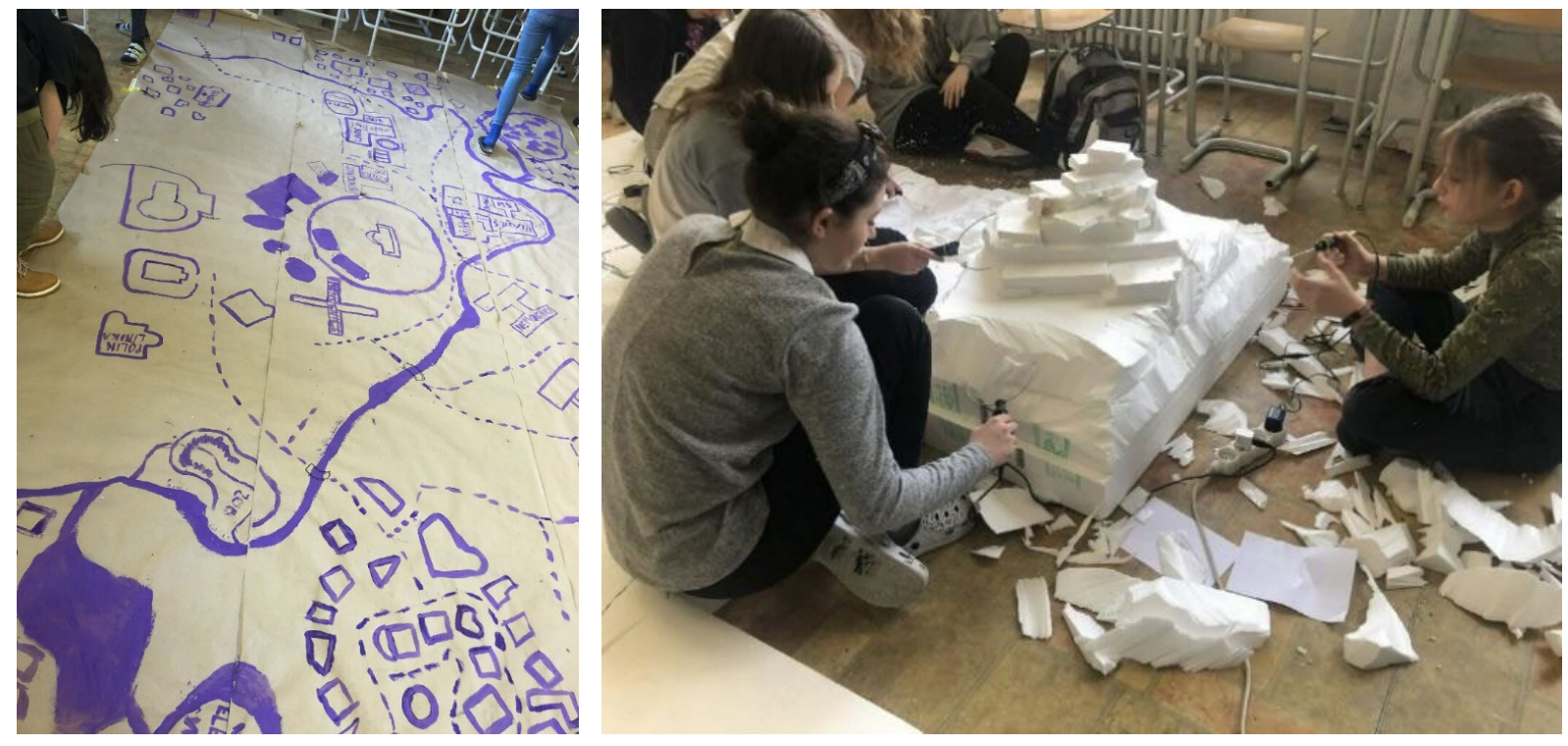

Žáci 7. třídy vytvářejí plán svého města. Žáci to hodnotili jako zajímavou zkušenost, která se však dramaticky změnila poté, co si uvědomili, že pro své město neurčili ani nevypracovali konkrétní př́rodní/fyzickogeografické prostředí. Tento důležitý moment byl př́íladem bohaté přiležitosti, kterou nabízí učení se z chyb, aniž by se žáci museli stydět nebo dostávat špatné známky. Vpravo: Žáci 7. trrídy vytvářejí strukturu prírodního prostředí svého města. Jednalo se o klíčový moment, kdy byli méně aktivní žáci motivováni k aktivnějšímu zapojení do práce.

- Kompetence spolupráce: důraz na práci v týmu, konflikt byl př́ležitostí zkoumat, jak respektujeme vyjadřování potřeb. Během navrhování a vytváření modelu města a při podpoře rozvoje kompetence spolupráce se uplatnily následující kreativní návyky mysli: poskytování a přijímání zpětné vazby, správné techniky spolupráce a sdílení výsledného produktu. Žáci sami zajímavě reflektovali kooperativní aspekt projektu:

„Jsme nakonec vytvořili nějaký kompromisy, podle mě nám ty odlišný názory i pomohly." žák 
„Pro mě bylo na projektu nejvíc překvapivé to, že jsme se dokázali celá třída shodnout na tom, co tam bude, protože se nám to většinou nedaři. I když poslední dobou je to čím dál častější, že se nám to povede." - žák

- Kritické myšlení a inovativní myšlení: žáci zpochybňovali architektonické normy. Cvičili svou představivost, pohrávali si s možnostmi a získávali odvahu lišit se prostřednictvím svých vlastních architektonických pokusů. To úzce souvisí s rozvojem:

- Anticipační kompetence - schopnost předvídání: hodnocení různých vizí budoucnosti a rozvoj vlastní představy o budoucnosti (viz níže fotky žáků při vytváření původních architektonických struktur).
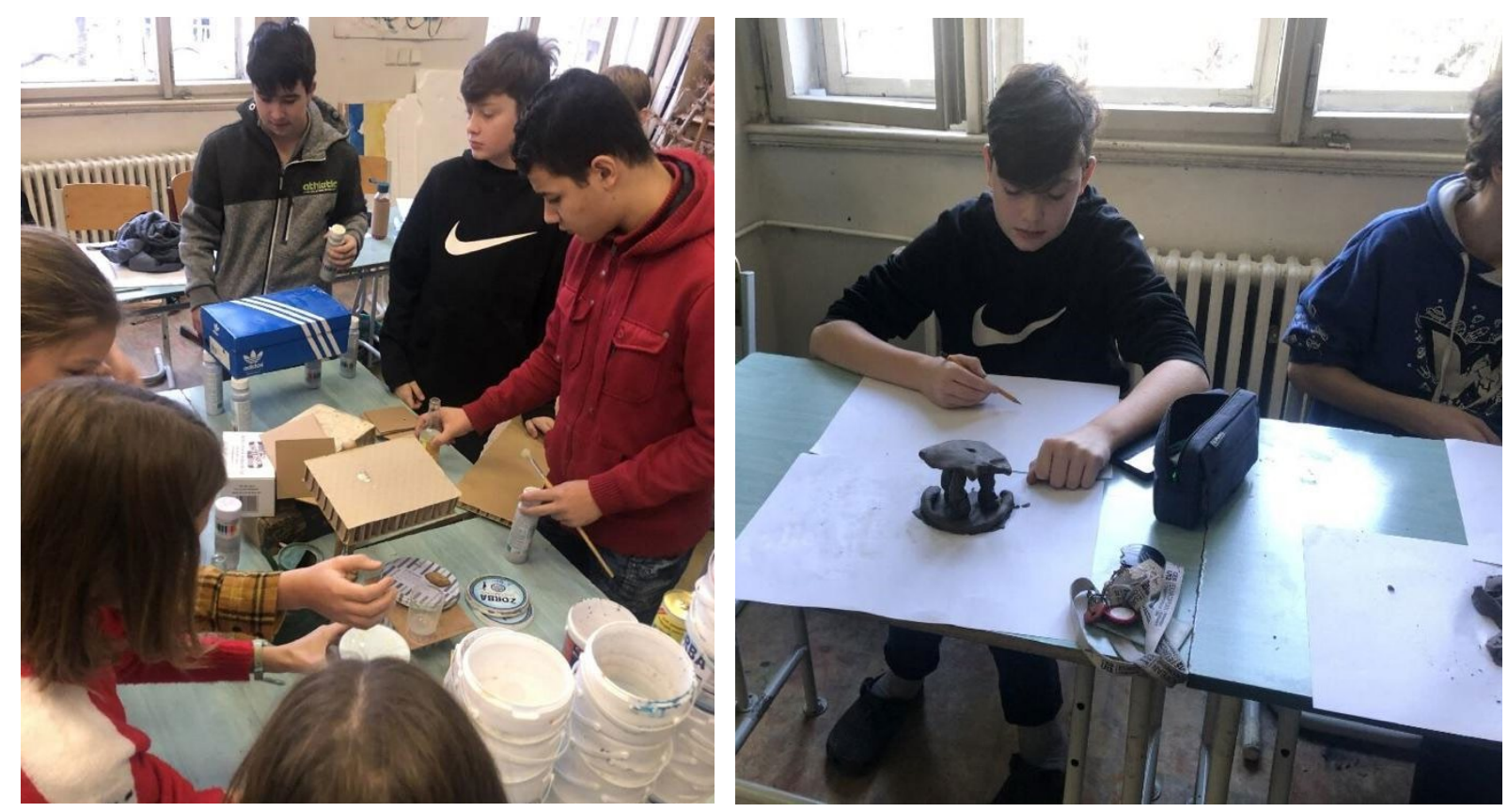

Žáci 7. tř́ídy zkoumají různé přístupy k modelování základních architektonických forem (vlevo: pomocí nalezených předmětů, vpravo: pomocí hlíny). 

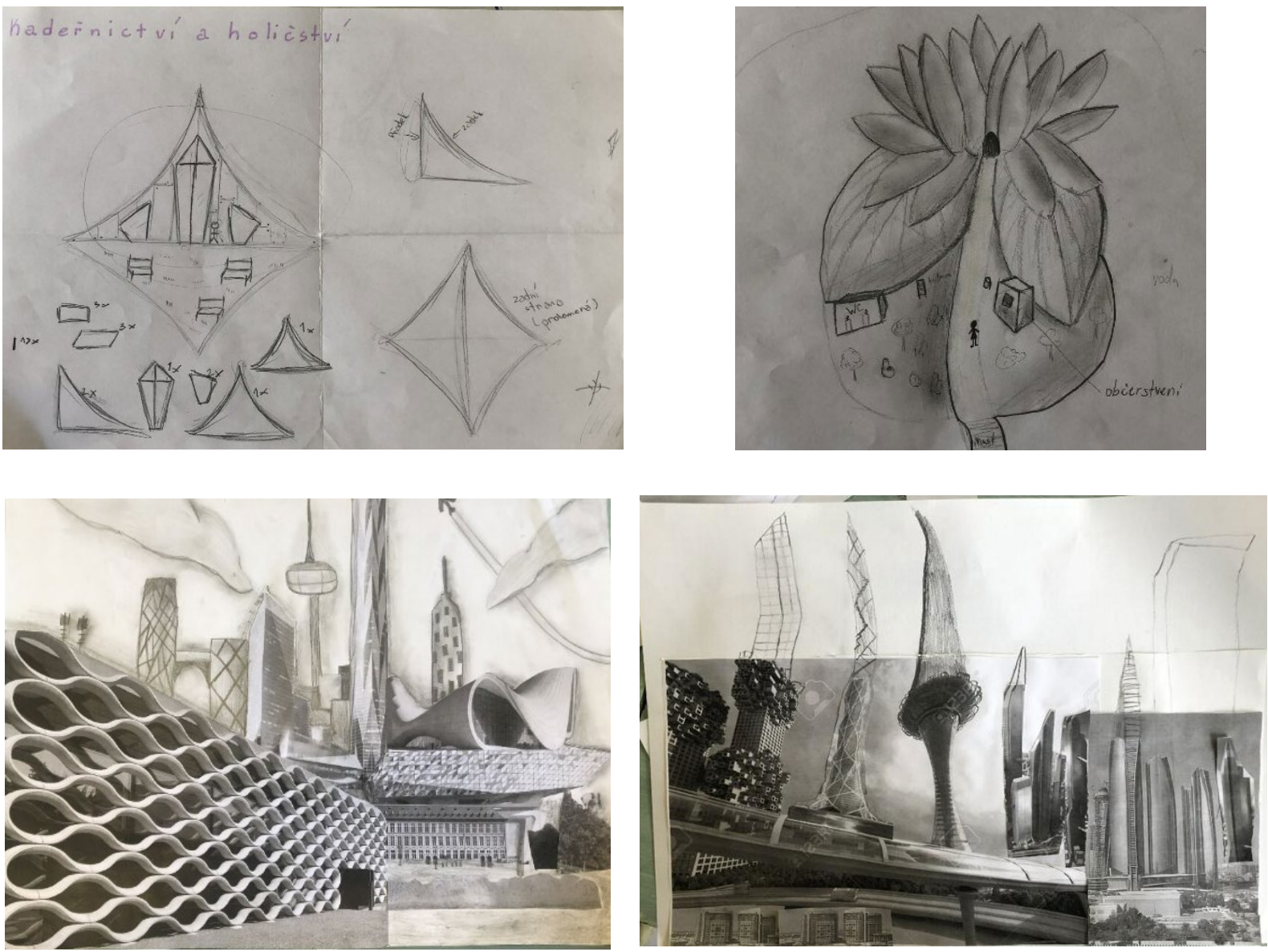

Práce žáků staví na kolážových obrázcích současné architektury a podněcuje jejich představivost o možných architektonických formách.

\section{Osobní príběh "Izolace"}

Projekt se zaměřoval na sebepoznání a sebereflexi v rámci vzdělávací oblasti Člověk a svět práce. $\checkmark$ předmětu výchova $\mathrm{k}$ volbě povolání žáci (8.třida) zpracovávali téma izolace, vlastním tvưrčím procesem reflektovali své pocity a snažili se zachytit změny ve svém vnitřním světě a světě kolem sebe v distančním období 2020. Žáci participovali na finalizaci tématu a volili si uměleckou formu podle své preference (kresba, malba, volné psaní, hudba). Práce žáků byla individuální - žáci tvořili samostatně ve svých domovech za použití prostředků a věcí, které je obklopovaly. Součástí byly individuální konzultace (tripartity) umělec, žák, učitel. Výstupem tématu byla videokoláž z prací žáků, která se stala historickou stopou roku 2020.

Syntéza kreativních návyků mysli a kompetencí pro udržitelnost v tomto školním projektu je jasně patrná na společném zapojení intuice, normativní kompetence a sebe-uvědomění. Žáci byli vedeni $\mathrm{k}$ tomu, aby naslouchali svému vnitřnímu hlasu a aby se nebáli vyjádřit něco hodně osobního, intimního, autentického a jedinečného (odvaha lišit se). Tento proces objevování podporoval rozvoj normativní kompetence skrze zkoumání hodnot, jako je svoboda, demokratické procesy, odpovědnost, komunita a propojení s ostatními. Byl to paralelní proces vytváření sebe-uvědomění: reflexe toho, co je pro mě důležité, jak mohu co nejautentičtěji vyjádřit své myšlenky a pocity. Tento proces byl pro mnoho žáků náročnou výzvou, ale prokázali velkou vytrvalost a zápal (vưle nevzdávat se ve chvilích, kdy se nedaří) a několik žáků prokázalo disciplinovanost, když předělávali svou práci, dokud neměli dojem, že je autentická a dokončená. 

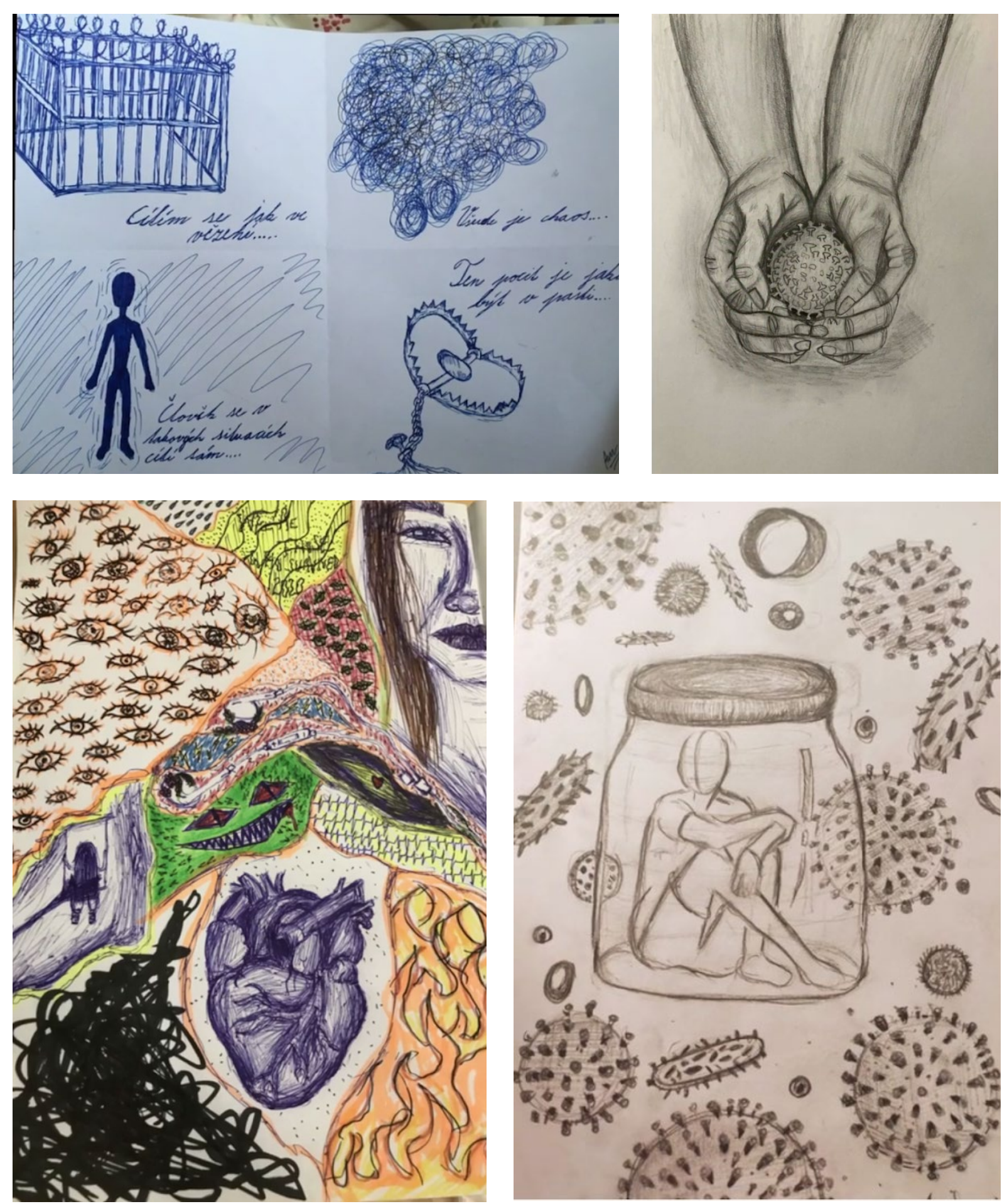

Práce a fragmenty procesu práce žáků osmé třídy na téma Izolace.

\section{Atria}

Žáci (8. třida) vytvářeli architektonické návrhy školních atrií, cílem bylo navrhnout venkovní učebny a prostory pro volný čas, podle potřeb a zájmů všech žáků i zaměstnanců školy. Žáci ve škole realizovali anketu, oslovovali i rodiče. Na základě výsledků ankety připravovali koncept, navrhovali prostory atrií a seznamovali se s celým procesem práce na architektonickém návrhu od zaměěení a focení prostor, rešerše, skicování, návrhů a modelování v PC až po tvorbu fyzického modelu. Žáci své návrhy prezentovali na radnici města a získali tak cennou zkušenost i zpětnou vazbu pro další 
práci. Žáci na projekt nahlíželi ekologickou perspektivou, pracovali s recyklovanými materiály a seznamovali s možným využitím recyklovaných materiálů v interiérovém (exteriérovém) designu a architektuře. Výstupem byly návrhy atrií v podobě architektonických modelů.

V projektu „Atria" docházelo k propojení učiva z matematiky, výtvarné a pracovní výchovy, informačních a komunikačních technologií, prírodopisu a českého jazyka. Zároveň rozvíjeli kompetence $\mathrm{k}$ udržitelnému rozvoji a kreativní návyky mysli - žáci byli iniciátory změny, která reagovala na potřeby všech žáků i příznivců školy. Rozvíjenými kompetencemi bylo

- Kritické myšlení: analýza výsledků ankety poskytla př́ležitost diskutovat o protichůdných názorech a hodnotách, které za nimi stojí.

- Sebe-uvědomění a sebepojetí žáků jako aktérů změny: praktické kroky $k$ uskutečnění změn, žáci dokázali přemýšlet o sobě samých a své roli v místní komunitě. Přes opakované přerušení výuky a zavření škol prokázali žáci velkou disciplinovanost a vytrvalost a chut́ dotáhnout projekt i ve velmi náročných podmínkách. Vyvinuli velké úsilí nad rámec toho, co od nich požadovali učitelé, aby mohli své nápady převést do 3D modelů.

- Spolupráce: prostřednictvím cvičení kreativních návyků mysli, jako je poskytování a prijímání zpětné vazby a správné techniky spolupráce, a sdílení "výsledného produktu", žáci rozvíjeli empatické vedení, které zlepšovalo atmosféru ve třídě.

- Anticipační kompetence: cvičení kreativních návyků mysli, jako je představivost, pohrávání si s možnostmi a tvorba alternativních vizí pro využití školních prostor, s důrazem na kroky potřebné $\mathrm{k}$ vytvoření kooperativních participativních vizí.

\section{Prezentace projektu na úřad městské části Praha 12}

"9. projektový den nás čekala cesta na úřad městské části Praha 4, kde jsme měli domluvené setkání žáků se zástupci MČ, kde měli žáci možnost prezentovat svojí dosavadní práci a vyslechnout si také vnější názory a nápady. Součástí "komise" na MČ byli zejm. pracovníci odboru životního prostředí, takže jim bylo téma rekultivace a návrhu vnějšího prostoru velmi blízké. Na konci prezentace byla také živá debata mezi žáky a zástupci MČ. Během prezentace ve škole, kdy jsme si to zkoušeli na nečisto jsem byl celkem zoufalí. Na úřadě měli najednou zapůsobit mezi cizími lidmi, kterých se tam nakonec sešlo mnohem víc, než jsme si všichni mysleli. Prezentace velmi vydařila a všichni najednou fungovali a moc hezky podali svojí práci a seznámili pracovníky úr̆adu s tím, o co se $v$ projektu snažíme." - umělec

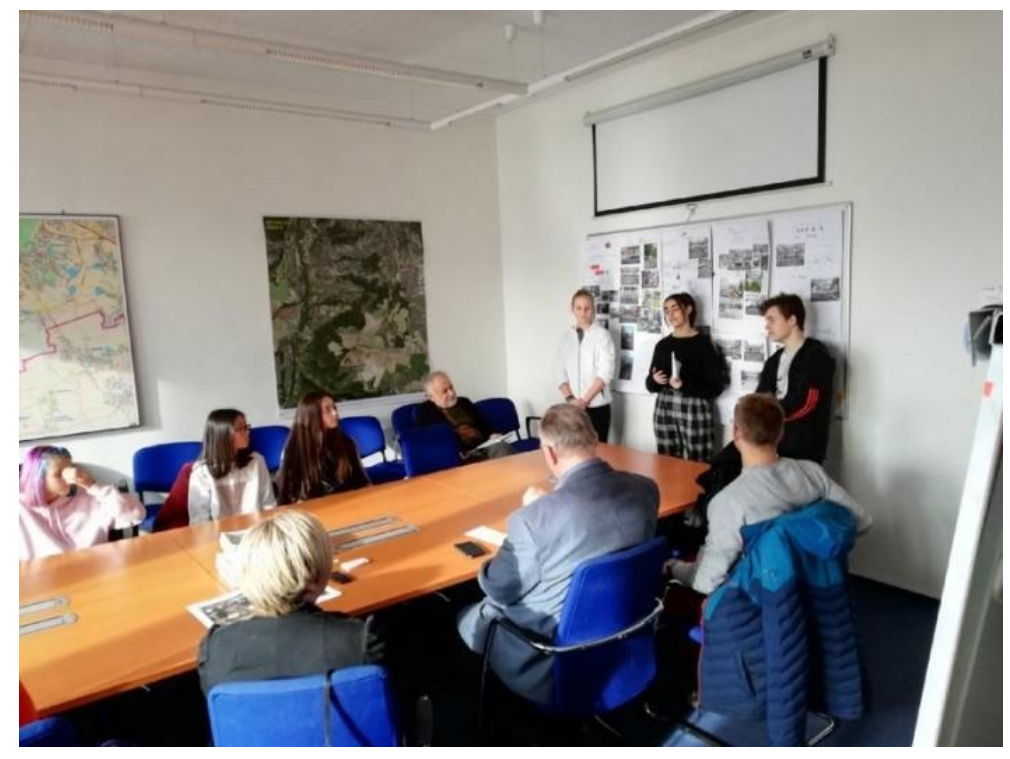

Žáci 8. tř́́dy představují městskému úřadu, včetně odborníka na udržitelnost a udržitelnou architekturu, své návrhy na rozvoj venkovních prostor školy. 


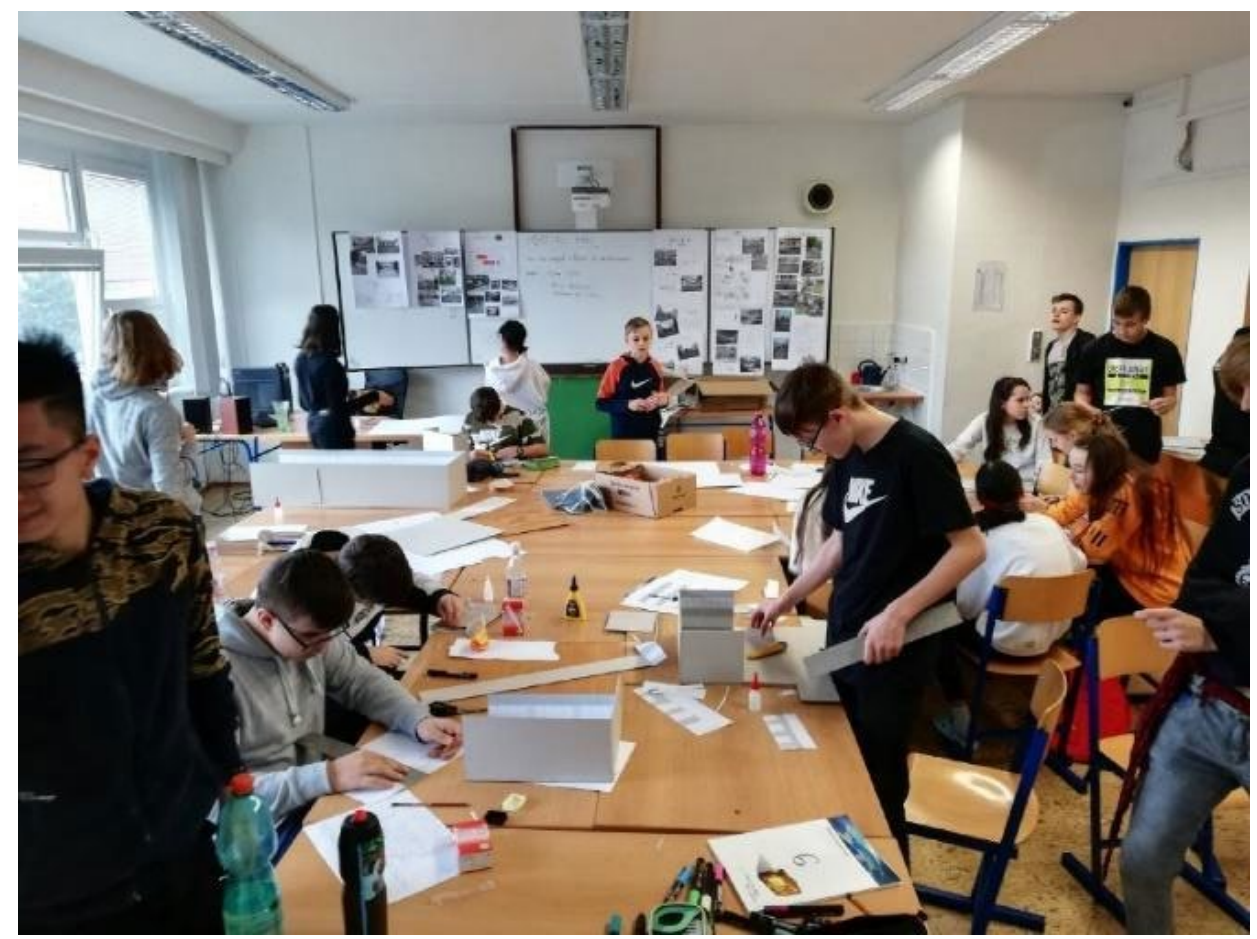

Žáci 8. třídy pracují v různě velkých skupinách na modelech svých návrhů atria.

\section{Diskuze}

Mezi přidané hodnoty kreativního procesu patří zkoumání a vyjadřování svého celého já (nejen verbálně), což žáci ve škole často nezažívají, stejně jako př́ležitost zapojit celý mozek, nejen jeho kognitivní procesy. Kreativní postupy ukázaly, že je možné podpořit kreativní a inovativní vize, jak dělat věci jinak, a zprostředkovat zkušenost $\mathrm{s}$ tvorbou nového. To samo o sobě dalo žákům pocítit, jaké to je vytvářet něco originálního a nového. Toto uvědomění je velice důležitým zdrojem při vytváření nových způsobů žití a bytí. Žáci dostali přiležitost využít svůj vlastní hlas a rozhodovat na úrovni jednotlivce i ve skupinách, měli možnost zakusit osobnostní růst, který je pak možné převést do jiných kontextů vně školní tř́ídy.

Pedagogové $v$ rozhovorech reflektovali nové dovednosti, které se $z$ jejich pohledu u žáků rozvinuly. Posun u žáků viděli především v rovině kooperativní, jako velký klad vnímali posun kompetencí spojených se skupinovou výukou a prací v týmu, se kterými žáci př́liš zkušeností ve většině prípadů neměli. Tento posun vedl $\mathrm{k}$ větší synergii celé třídy a potvrdili jej také žáci. Jako významný vnímáme také sociální aspekt. Třídní kolektivy se díky projektům více poznávaly a propojily.

V rámci dotazníků (viz př́loha 1 ) byli učitelé konfrontováni také s tím, jak se rozvíjely specifické žákovské kompetence $v$ průběhu školního projektu. Přehled toho, jak pedagogové vnímali rozvoj vybraných schopností žáků v prvním a druhém roce projektu, je znázorněn $v$ grafu 2 . $v$ tomto grafu vidíme, že pedagogové hodnotili rozvoj kompetencí žáků jako prohlubující se s postupem projektu z prvního do druhého roku. 
Graf 1. Vybrané žákovské kompetence pohledem pedagogů

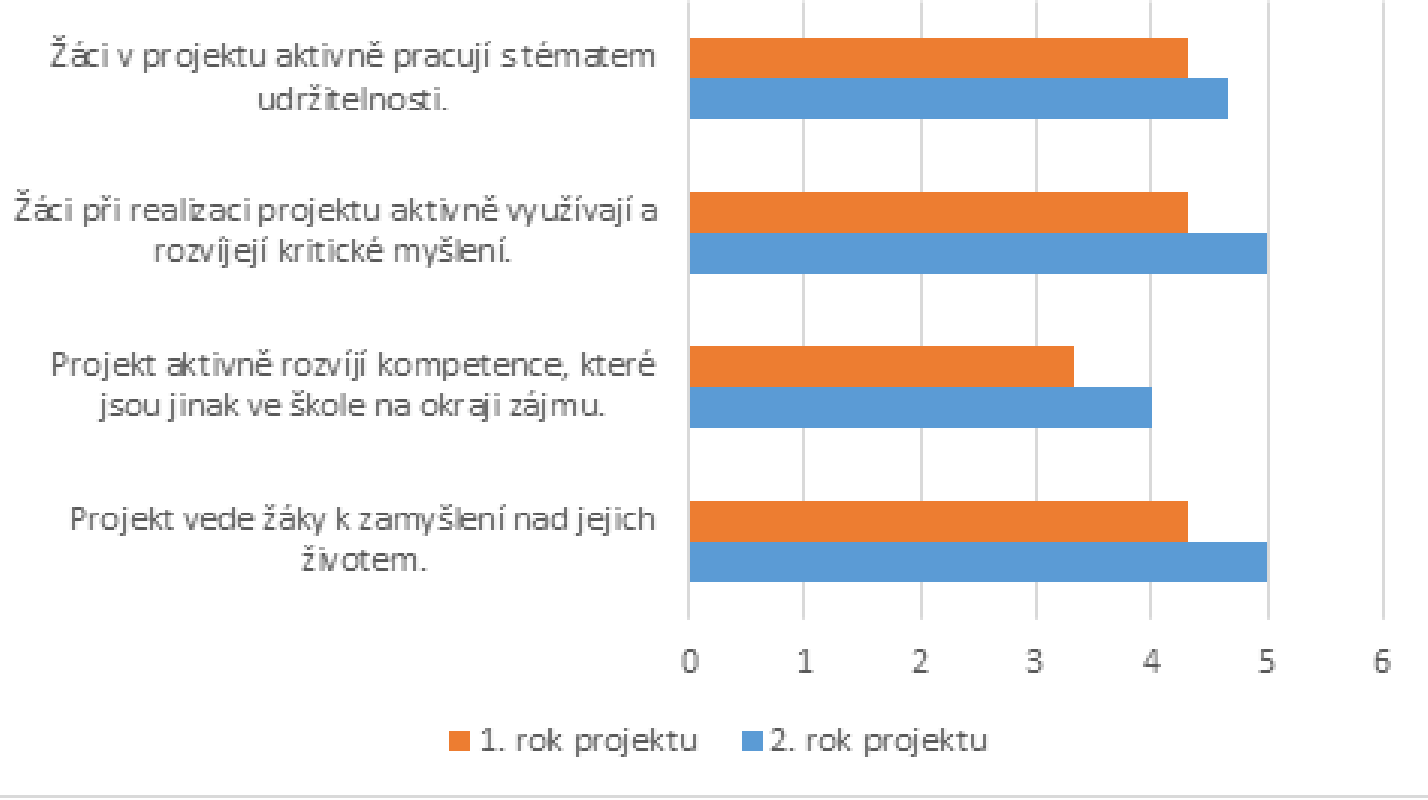

Jak vidno $z$ grafu, $v$ průběhu řešení žákovských projektů došlo $\mathrm{k}$ mírnému pozitivnímu posunu ve všech sledovaných aspektech, přičemž i "vstupni" hodnoty po prvním roce řešení projektu Ize vnímat jako vysoké až velmi vysoké.

Evaluace projektu VpB vedla k následujícím klíčovým zjištěním.

- Žáci dostávali dostatek prostoru pro vlastní rozhodování v průběhu řešení projektu, ale měli pouze omezený vliv na volbu tématu projektu.

- Všechny projekty pracovaly s vizí budoucnosti, at́ už vlastní nebo celé společnosti / planety.

- Témata spjatá s udržitelností byla zahrnuta ve všech projektech, byt' s odlišnou mírou. Starší žáci v některých prípadech pracovali přímo s Cíli udržitelného rozvoje a jejich interpretací.

- Postoj k propojení vzdělávání a angažovanosti není mezi učiteli jednotný, projekt vedl k většímu příklonu k roli vzdělávání pro přípravu angažovaného zapojení do řešení problémů společnosti.

- Propojení umění a vzdělávání, respektive výuka v tandemu umělec / učitel je přínosná pro všechny zúčastněné skupiny a Ize ji doporučit k širšímu využití.

- Př́nos dlouhodobých projektů, vedených tandemem umělec / učitel, se výrazně projevil v sociálních, diskuzních a kooperativních dovednostech žáků.

Z výsledků provedené evaluace Ize vyvodit sérii doporučení pro edukační realitu, která by mohla rozširirit paletu vzdělávacích přístupů na českých školách. Předně se jako velmi funkční jeví tandemová spolupráce pedagoga s umělcem. Tato spolupráce přináší do vzdělávání nové metody a kreativní techniky, nestranný pohled, osobu i profesi umělce jako vzor pro žáky a inovativní př́stupy, které mají pro žáky i učitele motivační charakter a vedou k zajímavým mezioborovým výsledkům.

Druhým doporučením pro české vzdělávání, které ve vInách zaznívá opakovaně, je širší zastoupení dlouhodobých projektů ve vzdělávání žáků. Cíle dlouhodobých projektů jsou relevantní ne- 
jen $v$ rovině kognitivní, ale především v rovině kompetenční, kdy žáci získávají dovednosti a kompetence potřebné $k$ řešení problémů a sofistikovaných projektů. At́ už je to schopnost hledání konsenzu a kompromisu, plánování, sběru externích dat, nebo prezentace výsledků stakeholderům mimo území školy. Jako významně progresivní se jeví také projektem akcentovaná kombinace vzdělávání k udržitelnosti, vzdělávání pro budoucnost a kreativního vzdělávání. Tento mix současných vzdělávacích proudů může pomoci připravovat žáky na situace, které je $v$ budoucím životě čekají a které jsou z hlediska současnosti nepredikovatelné.

\section{Závěr}

Aby vzdělávání pro udržitelnost mohlo být úspěšné a poskytlo příští generaci možnost vytvořit ekologicky zdravou a sociálně férovou budoucnost, je zásadní, aby se zaměřovalo na rozvoj kompetencí, aktivovalo afektivní doménu, vytvářelo př́ležitosti pro větší zapojení se, pro utváření vize a motivaci, a tím přispívalo $\mathrm{k}$ formování budoucnosti.

Analýza podobností a potenciálu pro syntézu dvou modelů kompetencí: klíčových kompetencí pro udržitelnost (UNESCO, 2017) a kreativních návyků mysli (Lucas et al., 2013) je originálním přínosem zde prezentovaného projektu Vzdělávání pro budoucnost. Článek dále popisuje pilotní implementaci navrženého vzdělávacího pedagogického přístupu ve čtyřech třídách na třech základních školách. Navrhovaný přistup vychází ze syntézy výše popsaných modelů pro rozvoj kompetencí a navrhuje pojem Vzdělávání pro budoucnost.

Z úvodní rešerše vyplývají některé překážky, které zpưsobují, že vzdělávání k udržitelnosti nevede ke společenské transformaci: nedokáže poskytnout mladým lidem kompetence $k$ akci (Jensen \& Schnack, 1997): má tendenci vycházet z transmisivních modelů vzdělávání (Jenkins, 2015); často ignoruje afektivní doménu, a tím pádem nevyužívá zapojení, vizi a motivaci žáků (Kollmuss \& Agyeman, 2002); a nedostatečně chápe způsob, jakým se budoucnost "přihodí. Pilotní projekty Vzdělávání pro budoucnost realizované autorským týmem byly krátce popsány spolu se shrnutím jejich dopadu, př́nosů a překážek. Participativní, kooperativní charakter školních projektů reaguje na zjištěnou potřebu přejít k socio-konstruktivistickým, transformativním modelům učení, na němž se žáci/žáci podílí (Wals a Jickling v Corcoran a Osano, 2009), a jsou zapojeni do učení formou spolupráce a kooperace (Jenkins, 2015). Nutnost vyhradit určitý čas na to, aby žáci mohli zkoumat své emoce, rozvíjet sebe-uvědomění, své hodnoty a vlastní roli v komunitě, reaguje na zjištěnou potřebu rozvinout kompetence především $v$ afektivní oblasti, která utváři základ pro aktivní občanství při řešení lokálních a globálních výzev. Projekt Vzdělávání pro budoucnost podporoval vztah žáků k přírodě a místu, kde žijí, otevřel jim možnost přemýšlet o tom, jakou budoucnost by chtěli zažít, a poskytl príležitost zakusit, jak by ji mohli sami vytvořit.

Model Vzdělávání pro budoucnost je $v$ současné době implementován v novém projektu nazvaném Školy pro budoucnost koordinovaném Společností pro kreativitu ve vzdělávání. Model je implementován ve dvaceti třídách na několika základních školách. Centrum pro otázky životního prostředí je partnerem projektu, který má na starost zhodnocení procesu a je zároveň hlavním partnerem v pracovní skupině rozvoje a hodnocení platformy uMĚNím pro kreativní učení, což je role, která poskytuje př́ležitost pro další výzkum tohoto modelu.

\section{Poděkování}

Článek je jedním z výsledků projektu „Vzdělání pro budoucnost” (TL02000081), který byl realizován s podporou Technologické agentury České republiky $v$ rámci programu na podporu aplikovaného společenskovědního a humanitního výzkumu, experimentálního vývoje a inovací ÉTA. K vytvoření podmínek pro tento výzkum přispěl nejen tým Centra pro otázky životního prostředí UK a kolegové ze Společnosti pro kreativitu ve vzdělávání, ale také četní učitelé a žáci ze zapojených škol. Za aktivní a podnětný přístup všech zúčastněných děkujeme! 


\section{Literatura}

- Abbs, P. (1989). A is for Aesthetic: Essays on Creative and Aesthetic Education. Psychology Press. https://doi.org/10.4324/9780203140307

- Ahlqvist, T., \& Rhisiart, M. (2015). Emerging pathways for critical futures research: Changing contexts and impacts of social theory. Futures, 71, 91-104. https://doi.org/10.1016/j.futures.2015.07.012

- Anděl, J. (2015). Why democracy needs the arts and culture [2nd Council of Europe Platform Exchange on Culture and Digitisation].

- Anderson, L., \& Krathwohl, D. A. (2001). Taxonomy for learning, teaching and assessing: A revision of Bloom's Taxonomy of Educational Objectives. New York: Longman.

- Anderson, T., \& Guyas, A. S. (2012). E<art>h Education, Interbeing, and Deep Ecology. Studies in Art Education, 53(3), 223-245. https://doi.org/10.1080/00393541.2012.11518865

- Apple, M. W. (2009, December 16). Global Crises, Social Justice, and Education. Global Crises, Social Justice, and Education. https://doi.org/10.4324/9780203861448-5

- Apple, M. W. (2013). Can education change society? Du Bois, Woodson and the politics of social transformation. Review of Education, 1(1), 32-56.

https://doi.org/10.1002/rev3.3000

- Bandura, A. (1977). Self-efficacy: Toward a unifying theory of behavioral change. 84(2), 191. Psychological Review, 8(2), 191. https://doi.org/10.1037/0033-295X.84.2.191

- Barth, M., Godemann, J., Rieckmann, M., \& Stoltenberg, U. (2007). Developing key competencies for sustainable development in higher education. International Journal of Sustainability in Higher Education. https://doi.org/10.1108/14676370710823582

- Barth, M., \& Michelsen, G. (2013). Learning for change: An educational contribution to sustainability science. Sustainability Science, 8(1), 103-119.

https://doi.org/10.1007/s11625-012-0181-5

- Bertling, J. G. (2015). The Art of Empathy: A Mixed Methods Case Study of a Critical PlaceBased Art Education Program. International Journal of Education \& the Arts, 16(Number 13). http://www.ijea.org/v16n13/index.html

- Biesta, G. (2009). Good education in an age of measurement: On the need to reconnect with the question of purpose in education. Educational Assessment, Evaluation and Accountability(Formerly: Journal of Personnel Evaluation in Education), 21(1), 33-46. https://doi.org/10.1007/s11092-008-9064-9

- Blandy, D., \& Fenn, J. (2012). Sustainability: Sustaining Cities and Community Cultural Development. Studies in Art Education, 53(4), 270-282. https://doi.org/10.1080/00393541.2012.11518869

- Bloom, B. S.; Engelhart, M. D.; Furst, E. J.; Hill, W. H.; Krathwohl, D. R. (1956). Taxonomy of educational objectives: The classification of educational goals. Handbook I: Cognitive domain. New York: David McKay Company.

- Blumenfeld, P. C., Kempler, T. M., \& Krajcik, J. S. (2005). Motivation and Cognitive Engagement in Learning Environments. In R. K. Sawyer (Ed.), The Cambridge Handbook of the Learning Sciences (pp. 475-488). Cambridge University Press. https://doi.org/10.1017/CBO9780511816833.029 
- Boström, M., Andersson, E., Berg, M., Gustafsson, K., Gustavsson, E., Hysing, E., Lidskog, R., Löfmarck, E., Ojala, M., \& Olsson, J. (2018). Conditions for transformative learning for sustainable development: A theoretical review and approach. Sustainability, 10(12), 4479. https://doi.org/10.3390/su10124479

- Bowers, C. A. (2001). Educating for Eco-justice and Community. University of Georgia Press.

- Bradshaw, R. D. (2016). Art Integration Fosters Empathy in the Middle School Classroom. The Clearing House: A Journal of Educational Strategies, Issues and Ideas, 89(4-5), 109117. https://doi.org/10.1080/00098655.2016.1170441

- Bruner, J. S. (1996). The Culture of Education. Harvard University Press.

- BuildingAgency_EducatorGuide.pdf. (n.d.). Retrieved 21 January 2021, from https://static1.squarespace.com/sta-

tic/5773dde903596ecc892de49f/t/57db2c601b631b6ed5a9145a/1473981539719/BuildingAgency EducatorGuide.pdf

- Burnaford, G., Brown, S., Doherty, J., \& McLaughlin, H. J. (2007). Arts Integration Frameworks, Research Practice-A literature Review. Arts Education Partnership. http://choice.dadeschools.net/rrm/resources/BurnafordArtsIntegrationFrameworksResearchPracticeALitReview.pdf

- Canning, D., Reinsborough, P., \& Smucker, J. M. (2017). Re: Imagining change: How to use story-based strategy to win campaigns, build movements, and change the world. Pm Press.

- Carolee, B., \& Heather, C. (2014). Shaping the future we want: UN Decade of Education for Sustainable Development; final report. UNESCO. https://library.wur.nl/WebQuery/wurpubs/fulltext/246667

- Catterall, C.S., \& Waldorf, L. (1999). Chicago arts partnerships in education: Summary evaluation in EB Fiske (Ed.) Champions of change: The impact of the arts on learning. The Arts Education Partnership and The President's Committee on the Arts and the Humanities. Washington, DC.

- Charland, W. (2011). Art Integration as School Culture Change: A Cultural Ecosystem Approach to Faculty Development. International Journal of Education \& the Arts, Volume 12 Number 8. http://www.ijea.org/v12n8/

- Christen, M., \& Schmidt, S. (2012). A Formal Framework for Conceptions of Sustainability a Theoretical Contribution to the Discourse in Sustainable Development: A Formal Framework for Conceptions of Sustainability. Sustainable Development, 20(6), 400-410. https://doi.org/10.1002/sd.518

- Clark, B., \& Button, C. (2011). Sustainability transdisciplinary education model: Interface of arts, science, and community (STEM). International Journal of Sustainability in Higher Education, 12(1), 41-54. https://doi.org/10.1108/14676371111098294

- Cole, A. G. (2007). Expanding the Field: Revisiting Environmental Education Principles Through Multidisciplinary Frameworks. The Journal of Environmental Education, 38(2), 3545. https://doi.org/10.3200/JOEE.38.1.35-46

- Collard, P., \& Looney, J. (2014). Nurturing creativity in education. European Journal of Education, 49(3), 348-364. https://doi.org/10.1111/ejed.12090 
- Conclusions of the Council and of the Representatives of the Governments of the Member States, meeting within the Council of 19 November 2010 - Access of young people to culture [Official Journal C 326, 3. 12. 2010]. (n.d.).

- Conkey, A., \& Green, M. (2018). Using place-based art education to engage students in learning about food webs. Journal of Instructional Pedagogies, 21. https://www.researchgate.net/publication/326830611 Using place-based art education to engage students in learning about food webs

- Convention on the Rights of the Child. (1990). UN General Assembly. http://wunrn.org/reference/pdf/Convention Rights Child.PDF

- Corcoran, P. B., Osano, P. M., Weakland, J. P., \& Hollingshead, B. P. (2009). Young People, Education, and Sustainable Development: Exploring Principles, Perspectives, and Praxis. Wageningen Academic Pub.

- Council of the European Union. (2008). Promoting creativity and innovation through education and training. Official Journal C 141 of 7. 6. 2008.

- Creativity, Culture and Education. (2009). Changing Young Lives 2012. Newcastle: CCE.

- Davis, J., \& Elliott, S. (2014). Research in Early Childhood Education for Sustainability: International perspectives and provocations. Routledge.

- Deasy, R. J. (2002). Critical Links: Learning in the Arts and Student Academic and Social Development. Arts Education Partnership, One Massachusetts Ave. https://eric.ed.gov/?id=ED466413

- DeMoss, K., \& Morris, T. (2002). How Arts Integration Supports Student Learning: Students Shed Light on the Connections. Chigaco Arts Partnership in Education, 25. http://capechicago.org/wp-content/uploads/2016/11/How-Arts-Integration-Supports-Student-LearningFull-Report-CAPE.pdf

- Dewey, J. (2005). Art as experience. Penguin.

- Dissanayake, Ellen. (1995). Homo Aestheticus Where Art Comes From and Why. University of Washington Press. http://www.washington.edu/uwpress/search/books/DISHOM.html

- Dlouhá, J., Henderson, L., Kroufek, R., Jančaříková, K., \& Neprašová, S. (2020). Udržitelná spotřeba a životní styl jako vzdělávací téma: Jaké vzdělávací cíle si stanovit, když chceme předjímat společenské změny? Envigogika, 15(1), https://doi.org/10.14712/18023061.608

- Dlouhá, J., Heras, R., Mulà, I., Salgado, F. P., \& Henderson, L. (2019). Competences to Address SDGs in Higher Education-A Reflection on the Equilibrium between Systemic and Personal Approaches to Achieve Transformative Action. Sustainability, 11(13), 3664. https://doi.org/10.3390/su11133664

- Duma, A., \& Silverstein, L. (2014). A View into a Decade of Arts Integration. Journal for Learning through the Arts: A Research Journal on Arts Integration in Schools and Communities, 10(1). https://doi.org/10.21977/D910119197

- Duncombe, S. (2019). Dream or nightmare: Reimagining politics in an age of fantasy. OR Books.

- Duncombe, Stephen. (2012). Introduction: Open Utopia | The Open Utopia. http://theopenutopia.org/full-text/introduction-open-utopia/ 
- ECE, U. (2011). Learning for the future: Competences in Education for Sustainable Development. Geneva, United Nations Economic Commission for Europe, Steering Committee on Education for Sustainable Development.

- Eernstman, N., \& Wals, A. (2013). Locative meaning-making: An arts-based approach to learning for sustainable development. Sustainability, 5(4), 1645-1660. https://doi.org/10.3390/su5041645

- Efland, A. (2002). Art and Cognition: Integrating the Visual Arts in the Curriculum. Teachers College Press.

- Eilam, E., \& Trop, T. (2010). ESD Pedagogy: A Guide for the Perplexed. The Journal of Environmental Education, 42(1), 43-64. https://doi.org/10.1080/00958961003674665

- Eisner, E. W. (1979). The educational imagination: On the design and evaluation of school programs. New York: Macmillan.

- Ellen, W., \& Stéphan, V.-L. (2013). Educational research and innovation art for art's sake? The impact of arts education: The Impact of Arts Education. OECD publishing.

- Elliot, J. (1991). Action research for educational change. McGraw-Hill Education (UK).

- Emery, S. (2013). Making the case for "arts for sustainability": a study of educators' views of education for sustainability. A Dissertation Submitted to the Faculty of Education of the University of Tasmania at Launceston in Partial Fulfilment of the Requirements of the Degree of Master of Education, 108.

- Everett, L., Noone, G., Brooks, M., \& Littledyke, R. (2015). Sustainability and the Creative Arts. In N. Taylor, F. Quinn, \& C. Eames (Eds.), Educating for Sustainability in Primary Schools: Teaching for the Future (pp. 221-245). SensePublishers. https://doi.org/10.1007/978-94-6300-046-8_11

- Ewing, R. (2011). The arts and Australian education: Realising potential. https://research.acer.edu.au/cgi/viewcontent.cgi?referer=https://scholar.google.cz/\&httpsre$\mathrm{dir}=1 \&$ article $=1020 \&$ context $=$ aer

- Fielding, M. (2004). Transformative approaches to student voice: Theoretical underpinnings, recalcitrant realities. British Educational Research Journal, 30(2), 295-311. https://doi.org/10.1080/0141192042000195236

- Finley, S. (2011). Ecoaesthetics: Green arts at the intersection of education and social transformation. Cultural Studies? Critical Methodologies, 11(3), 306-313. https://doi.org/10.1177/1532708611409549

- Fischer, D., \& Barth, M. (2014, July). Key Competencies for and beyond Sustainable Consumption An Educational Contribution to the Debate. https://doi.org/info:doi/10.14512/gaia.23.S1.7

- Foucalt, M. (1975). Discipline and Punish. Gallimard.

- Fredricks, J. A., Blumenfeld, P. C., \& Paris, A. H. (2004). School Engagement: Potential of the Concept, State of the Evidence. Review of Educational Research, 74(1), 59-109. https://doi.org/10.3102/00346543074001059

- Freire, P. (1970). Pedagogy of the Oppressed. Continuum International Publishing Group. 
- Fulton, L. A., \& Simpson-Steele, J. (n.d.). Reconciling the Divide: Common Processes in Science and Arts Education. Retrieved 26 June 2019, from https://scholarship.claremont.edu/steam/vol2/iss2/3/

- Gablik, S. (1992). Connective Aesthetics. American Art, 6(2), 2-7. https://doi.org/10.1086/424147

- Gardner, H. (1983). Frames of mind: The theory of multiple intelligences. New York Basic Books.

- Gardner, H. (1990). Art Education and Human Development. Getty Publications.

- Gidley, J., Bateman, D., \& Smith, C. (2004). Futures in Education: Principles, practices and potential, (Monograph No 5; The Strategic Foresight Monograph Series).

- Giroux, H. A. (2003). Public pedagogy and the politics of resistance: Notes on a critical theory of educational struggle. Educational Philosophy and Theory, 35(1), 5-16. https://doi.org/10.1111/1469-5812.00002

- Goleman, D. (1995). Emotional intelligence. Bantam. https://www.360talentmasters.com/wp-content/uploads/2016/08/Emotional.pdf

- Goodson, I. F., Biesta, G., Tedder, M., \& Adair, N. (2010). Narrative Learning. London and New York: Routledge.

- Gotlieb, R., Jahner, E., Immordino-Yang, M. H., \& Kaufman, S. B. (2017). How Social-Emotional Imagination Facilitates Deep Learning and Creativity in the Classroom. In R. A.

Beghetto \& J. C. Kaufman (Eds.), Nurturing Creativity in the Classroom (2nd ed., pp. 308336). Cambridge University Press. https://doi.org/10.1017/9781316212899.018

- Gough, N. (1990). Futures in Australian education-Tacit, token and taken for granted. Futures, 22(3), 298-310. https://doi.org/10.1016/0016-3287(90)90149-C.

- Gradle, S. (2007). Ecology of Place: Art Education in a Relational World. Studies in Art Education, 48(4), 392-411. https://doi.org/10.1080/00393541.2007.11650116

- Graham, M. A. (2007). Art, Ecology and Art Education: Locating Art Education in a Critical Place-based Pedagogy. Studies in Art Education, 48(4), 375-391. https://doi.org/10.1080/00393541.2007.11650115

- Greene, M. (1995). Releasing the imagination: Essays on education, the arts, and social change. Jossey-Bass.

- Gruenewald, D. A. (2003). The best of both worlds: A critical pedagogy of place. Educational Researcher, 32(4), 3-12. https://doi.org/10.3102/0013189X032004003

- Gullatt, D. E. (2008). Enhancing Student Learning through Arts Integration: Implications for the Profession. The High School Journal, 91(4), 12-25. JSTOR.

- Hallmark, E. F. (2012). Challenge: The Arts as Collaborative Inquiry. Arts Education Policy Review, 113(3), 93-99. https://doi.org/10.1080/10632913.2012.687336

- Hedefalk, M., Almqvist, J., \& Lidar, M. (2014). Teaching for Action Competence. SAGE Open, 4(3), 2158244014543785. https://doi.org/10.1177/2158244014543785

- Heft, H., \& Chawla, L. (2006). Children as agents in sustainable development: The ecology of competence. In Children and their environments: Learning, using and designing spaces. Cambridge University Press. 
- Henderson, L., \& Dlouhá, J. (2021). Myšlení budoucnosti a potřebnost transformativního př́stupu ve vzdělávání. Envigogika, 16(1). https://doi.org/10.14712/18023061.621.

- Hetland, L., \& Winner, E. (2001). The Arts and Academic Achievement: What the Evidence Shows. Arts Education Policy Review, 102(5), 3-6. https://doi.org/10.1080/10632910109600008

- Hicks, D. (2002). Postmodern education: A futures perspective. In Advancing Futures (pp. 321-330). Praeger.

- hooks, bell. (2014). Teaching to transgress. Routledge.

- Hopkins, R. (2019). From What Is to What If: Unleashing the power of imagination to create the future we want. Chelsea Green Publishing.

- Huckle, J., \& Wals, A. E. J. (2015). The UN Decade of Education for Sustainable Development: Business as usual in the end. Environmental Education Research, 21(3), 491-505. https://doi.org/10.1080/13504622.2015.1011084

- Hunter, M. A., Aprill, A., Hill, A., \& Emery, S. (2018). Education, arts and sustainability: Emerging practice for a changing world. Springer.

- Immordino-Yang, M. H., \& Damasio, A. (2007). We feel, therefore we learn: The relevance of affective and social neuroscience to education. Mind, Brain, and Education, 1(1), 3-10. https://doi.org/10.1111/j.1751-228X.2007.00004.x

- Inayatullah, S. (2008). Six pillars: Futures thinking for transforming. Foresight, 10(1), 421. https://doi.org/10.1108/14636680810855991

- Inwood, H. (2008). Mapping Eco-Art Education. Canadian Review of Art Education: Research and Issues, 35, 57-73. https://eric.ed.gov/?id=EJ822675

- Inwood, H. J. (2008). At the Crossroads: Situating Place-based Art Education. Canadian Journal of Environmental Education, 13(1), 13. https://eric.ed.gov/?id=EJ842767

- Jacobson, S. K., Mcduff, M. D., \& Monroe, M. C. (2007). Promoting Conservation through the Arts: Outreach for Hearts and Minds. Conservation Biology, 21(1), 7-10. https://doi.org/10.1111/j.1523-1739.2006.00596.x

- Jenkins, K. (2015). How to Teach Education for Sustainability. In N. Taylor, F. Quinn, \& C. Eames (Eds.), Educating for Sustainability in Primary Schools: Teaching for the Future (pp. 33-43). SensePublishers. https://doi.org/10.1007/978-94-6300-046-8 3

- Jensen, B. B., \& Schnack, K. (1997). The Action Competence Approach in Environmental Education. Environmental Education Research, 3(2), 163-178. https://doi.org/10.1080/1350462970030205

- Johnson, M. (2007). The Meaning of the Body: Aesthetics of Human Understanding. The University of Chicago Press.

- Jónsdóttir, Á. (2013). Art and place-based education for the understanding of sustainability. Education in the North, 20, 90-105. https://www.abdn.ac.uk/education/documents/journals documents/Volume\%2020\%20Special\%20Issue/EITN\%20Volume $\% 2020 \% 20$ Article\%206.pdf

- Juman Abujbara, Boyd, A., Mitchel, D., \& Taminato, M. (2012). Beautiful Trouble. OR Books. 
- Kennedy, J. F. (1969). The John F. Kennedy Center for the Performing Arts. Performing Arts Review, 1(2), 341-364. https://doi.org/10.1080/00315249.1969.9943914

- Kollmuss, A., \& Agyeman, J. (2002). Mind the Gap: Why do people act environmentally and what are the barriers to pro-environmental behavior? Environmental Education Research, 8(3), 239-260. https://doi.org/10.1080/13504620220145401

- Krathwohl, D., Bloom, B., Masia, B. (1964). Taxonomy of Educational Objectives: The Classification of Educational Goals. New York, NY: Longman, Inc.

- Krathwohl, D. R., Bloom, B. S., \& Masia, B. B. (1973). Taxonomy of educational objectives, the classification of educational goals. Handbook II: affective domain. David McKay Co. Inc., New York, 1, 956.

- $\quad$ Lawrence, R. L. (2008). Powerful feelings: Exploring the affective domain of informal and arts-based learning. New Directions for Adult and Continuing Education, 2008(120), 65-77. https://doi.org/10.1002/ace.317

- $\quad$ Leicht, A., Heiss, J., \& Byun, W. J. (2018). Issues and trends in education for sustainable development (Vol. 5). UNESCO publishing.

- Lemoine, S., \& Ouardi, S. (2010). Artivisme: Art, action politique et résistance culturelle. Alternatives.

- Liao, C. (2016). From interdisciplinary to transdisciplinary: An arts-integrated approach to STEAM education. Art Education, 69(6), 44-49. https://doi.org/10.1080/00043125.2016.1224873

- Littledyke, M. (2009). Education for Sustainability in the Primary Curriculum: A Guide for Teachers. Palgrave Macmillan.

- Lucas, B. (2016). A Five Dimensional Model of Creativity and its Assessment in Schools. Applied Measurement in Education, 29(4), 278-290. https://doi.org/10.1080/08957347.2016.1209206

- Lucas, B., Claxton, G., \& Spencer, E. (2012). Making It: Studio teaching and its impact on teachers and learners. https://cris.winchester.ac.uk/ws/portalfiles/portal/356957/85Claxton\%2C_Lucas_and_Spencer_2012_Making_It_Studio_teaching_and_its_impact on teachers a.pdf

- Lucas, B., Claxton, G., \& Spencer, E. (2014). Progression in student creativity in school: First steps towards new forms of formative assessments. Contemporary Readings in Law \& Social Justice, 6(2). https://www.oecd-ilibrary.org/education/progression-in-student-creativity-in-school 5k4dp59msdwk-en

- Lundy, L. (2007). 'Voice' is not enough: Conceptualising Article 12 of the United Nations Convention on the Rights of the Child. British Educational Research Journal, 33(6), 927942. https://doi.org/10.1080/01411920701657033

- Mantere, M.-H. (1998). Art and the Environment-An Art-based Approach to Environmental Education (No. 3; Rapporter Om Utbildning).

- Manyika, J., Chui, M., Miremadi, M., Bughin, J., George, K., Willmott, P., \& Dewhurst, M. (2017). Harnessing automation for a future that works. McKinsey Global Institute. 
- Marope, M., Griffin, P., \& Gallagher, C. (2017). Future competences and the future of curriculum: A global reference for curricula transformation. International Bureau of Education. IBE-UNESCO. http://www.ibe.unesco.org/sites/default/files/resources/future_competences and the future of curriculum.pdf

- Marsh, J. (2010). Childhood, culture and creativity: A literature review. Creativity, Culture and Education.

- Marshall, J. (2005). Connecting Art, Learning, and Creativity: A Case for Curriculum Integration. Studies in Art Education, 46(3), 227-241. https://doi.org/10.1080/00393541.2005.11650076

- Marshall, J. (2014). Transdisciplinarity and art integration: Toward a new understanding of art-based learning across the curriculum. Studies in Art Education, 55(2), 104-127. https://doi.org/10.1080/00393541.2014.11518922

- Mason, C. Y., Steedly, K. M., \& Thormann, M. S. (2008). Impact of Arts Integration on Voice, Choice, and Access. Teacher Education and Special Education, 31(1), 36-46. https://doi.org/10.1177/088840640803100104

- McGregor, C. (2012). Art-informed pedagogy: Tools for social transformation. International Journal of Lifelong Education, 31(3), 309-324. https://doi.org/10.1080/02601370.2012.683612

- McInerney, P., Smyth, J., \& Down, B. (2011). 'Coming to a place near you?'The politics and possibilities of a critical pedagogy of place-based education. Asia-Pacific Journal of Teacher Education, 39(1), 3-16. https://doi.org/10.1080/1359866X.2010.540894

- McLaren, P. (2015). Life in Schools: An Introduction to Critical Pedagogy in the Foundations of Education. Routledge. https://doi.org/10.4324/9781315633640

- Mcmullen, B., \& Fletcher, P. (2015). An Inquiry-Based Cross-Curriculum Approach. In N. Taylor, F. Quinn, \& C. Eames (Eds.), Educating for Sustainability in Primary Schools: Teaching for the Future (pp. 269-302). SensePublishers. https://doi.org/10.1007/978-94$\underline{6300-046-8 \quad 13}$

- Mesías-Lema, J. M. (2018). Artivism and Social Conscience: Transforming Teacher Training from a Sensibility Standpoint. Comunicar: Media Education Research Journal, 26(57), 1928. https://doi.org/10.3916/C57-2018-02

- Mezirow, J. (1997). Transformative learning: Theory to practice. New Directions for Adult and Continuing Education, 1997(74), 5-12.

- Mezirow, J. (2003). Transformative learning as discourse. Journal of Transformative Education, 1(1), 58-63. https://www.ecolas.eu/eng/wp-content/uploads/2015/10/MezirowTransformative-Learning.pdf

- Milton, K. (2003). Loving Nature: Towards an Ecology of Emotion. Routledge. https://doi.org/10.4324/9780203421413

- Mochizuki, Y., \& Fadeeva, Z. (2010). Competences for sustainable development and sustainability. International Journal of Sustainability in Higher Education. https://doi.org/10.1108/14676371011077603

- National Advisory Committee on Creative and Cultural Education. (1999). All Our Futures: Creativity, Culture and Education (p. 243). DFEE. 
- Navrátil, O. (2012). In Between Environmental Art and Environmental Education. Envigogika, 7(2). https://doi.org/10.14712/18023061.72

- Nilson, C., Fetherston, C. M., McMurray, A., \& Fetherston, T. (2013). Creative arts: An essential element in the teacher's toolkit when developing critical thinking in children. Australian Journal of Teacher Education (Online), 38(7), 1.

- OECD. (2018). Preparing our youth for an inclusive and sustainable world. https://www.oecd.org/education/Global-competency-for-an-inclusive-world.pdf

- Ofsted. (2006). Creative partnerships: Initiative and impact,. Ofsted, London.

- Olssen, M., \& Peters, M. A. (2005). Neoliberalism, higher education and the knowledge economy: From the free market to knowledge capitalism. Journal of Education Policy, 20(3), 313-345. https://doi.org/10.1080/02680930500108718

- Oosterhuis, R. (2012). Doing well and doing good by doing art: A 12-year National Study of Education in the visual and performing arts . Cultural Trends, 21(4), 336-338. https://doi.org/10.1080/09548963.2012.741353

- Orr, D. W. (2004). Earth in Mind: On Education, Environment, and the Human Prospect. Island Press.

- Percy-Smith, B. (2009). A Handbook of Children and Young People's Participation: Perspectives from Theory and Practice (1st ed.). Routledge. https://doi.org/10.4324/9780203871072

- Percy-Smith, B., \& Burns, D. (2013). Exploring the role of children and young people as agents of change in sustainable community development. Local Environment, 18(3), 323339. https://doi.org/10.1080/13549839.2012.729565

- Plucker, J. A., Kaufman, J. C., \& Beghetto, R. A. (2015). What we know about creativity. Washington, DC: Partnership for 21st Century Learning.

- Rat, E. (2010). Conclusions of the Council and of the Representatives of the Governments of the Member States, meeting within the Council, on the Work Plan for Culture 2011-2014. Official Journal of the European Union (2010/C 325/01).

- Rautins Respress, T., \& Lufti, G. (2006). Whole Brain Learning: The Fine Arts with Students at Risk. Reclaiming Children and Youth, 15(1), 24-31.

- Respress, T., \& Lutfi, G. (2006). Whole brain learning: The fine arts with students at risk. Reclaiming children and youth, 15(1), 24.

- Rieckmann, M. (2017). Education for Sustainable Development Goals: Learning Objectives. UNESCO Publishing.

- Rinne, L., Gregory, E., Yarmolinskaya, J., \& Hardiman, M. (2011). Why Arts Integration Improves Long-Term Retention of Content. Mind, Brain, and Education, 5(2), 89-96. https://doi.org/10.1111/j.1751-228X.2011.01114.x

- Russell, J., \& Zembylas, M. (2007). Arts integration in the curriculum: A review of research and implications for teaching and learning. In International handbook of research in arts education (pp. 287-312). Springer. https://www.researchgate.net/profile/Sarah_Mccarthey/publication/226239480_Four_Metaphors_of_the_Composing_Process/links/54db67a70cf261ce15d01c99/Four-Metaphors-of-the-Composing-Process.pdf \#page $=294$ 
- Scheffer, M., Baas, M., \& Bjordam, T. (2017). Teaching originality? Common habits behind creative production in science and arts. Ecology and Society, 22(2).

https://doi.org/10.5751/ES-09258-220229

- Schultz, P. W. (2000). Empathizing With Nature: The Effects of Perspective Taking on Concern for Environmental Issues. Journal of Social Issues, 56(3), 16.

https://doi.org/10.1111/0022-4537.00174

- Scripp, L., \& Yung-Chin Paradis, L. (2013). Meeting the burden of proof: Statistical evidence for the impact of arts integration based on causal links among teacher professional development, arts learning and academic outcomes. CAPE. http://capechicago.org/wp-content/uploads/2016/11/PAIR-Abridged-Report-CAPE.pdf

- Scripp, L., \& Paradis, L. (2014). Embracing the Burden of Proof: New Strategies for Determining Predictive Links between Arts Integration Teacher Professional Development, Student Arts Learning, and Student Academic Achievement Outcomes. Journal for Learning through the Arts, 10(1). https://eric.ed.gov/?id=EJ1050591

- Shimshon-Santo, A. (2010). Arts = Education. University of California Press in association with the Center for Learning Through the Arts and Technology at University of California, Irvine Publication. https://www.academia.edu/12619334/Arts Education

- Shrivastava, P., Ivanaj, V., \& Ivanaj, S. (2012). Sustainable development and the arts. International Journal of Technology Management, 60(1/2), 23.

https://doi.org/10.1504/IJTM.2012.049104

- Silverstein, L. B., \& Layne, S. (2010). Defining Arts Integration. The John F. Kennedy Center for the Performing Arts.

- Singleton, J. (2015). Head, heart and hands model for transformative learning: Place as context for changing sustainability values. Journal of Sustainability Education, 9, 16. https://www.creativityandchange.ie/wp-content/uploads/2017/06/Singleton-JSE-March2015-Love-Issue.pdf

- Sipos, Y., Battisti, B., \& Grimm, K. (2008). Achieving transformative sustainability learning: Engaging head, hands and heart. International Journal of Sustainability in Higher Education, 9(1), 68-86. https://doi.org/10.1108/14676370810842193

- Slavík, J., Janík, T., Najvar, P., \& Knecht, P. (2017). Transdisciplinární didaktika: O učitelském sdílení znalostí a zvyšování kvality vỳuky napříč obory. Masarykova univerzita, Pedagogická fakulta.

- Sobel, D. (2010). Education for Sustainability in the Primary Curriculum: A Guide for Teachers. Edited by Michael Littledyke, Neil Taylor \& Chris Eames. South Yarra: Palgrave Macmillan, 2009, 262 pp. ISBN: 9781420256277. Australian Journal of Environmental Education, 26, 104-106. https://doi.org/10.1017/S0814062600000860

- Spencer, C., \& Blades, M. (2006). Children and their Environments: Learning, Using and Designing Spaces. Cambridge University Press.

- Steffen, W., Broadgate, W., Deutsch, L., Gaffney, O., \& Ludwig, C. (2015). The trajectory of the Anthropocene: the great acceleration. The Anthropocene Review, 2(1), 81-98. https://doi.org/10.1177\%2F2053019614564785

- Sterling, S. (2010). Learning for resilience, or the resilient learner? Towards a necessary reconciliation in a paradigm of sustainable education. Environmental Education Research, 16(5-6), 511-528. https://doi.org/10.1080/13504622.2010.505427 
- Taylor, E. W. (1998). The theory and practice of transformative learning: A critical review. Columbus, Ohio: ERIC Clearinghouse on Adult, Career, and Vocational Education. http://www.eric.ed.gov/ERICWebPortal/detail?accno=ED423422

- Taylor, N., Quinn, F., \& Eames, C. (2015a). Educating for Sustainability in Primary Schools: Teaching for the Future. SensePublishers.

- Taylor, N., Quinn, F., \& Eames, C. (2015b). Why do We Need to Teach Education for Sustainability at the Primary Level? In N. Taylor, F. Quinn, \& C. Eames (Eds.), Educating for Sustainability in Primary Schools: Teaching for the Future (pp. 1-11). SensePublishers. https://doi.org/10.1007/978-94-6300-046-8 1

- The Chicago Guide for Teaching and Learning in the Arts. (n.d.). Chicago Public Schools Office of Arts Education. http://www.cpsarts.org/wp-content/uploads/2018/03/ChicagoGuide-Arts-Scope-Sequence.pdf

- Theis, J. (2010). Children as active citizens: An agenda for children's civil rights and civic engagement. In A Handbook of Children and Young People's Participation. Routledge.

- Thomson, P., Hall, C., Sefton-Green, J., \& Jones, K. (2012). The Signature Pedagogies Project: Final Report. London: Creativity, Culture and Education.

- Twenge, J. M., Zhang, L., \& Im, C. (2004). It's beyond my control: A cross-temporal metaanalysis of increasing externality in locus of control, 1960-2002. Personality and Social Psychology Review, 8(3), 308-319. https://doi.org/10.1207\%2Fs15327957pspr0803_5

- UNESCO. (2014). UNESCO roadmap for implementing the Global Action Programme on Education for Sustainable Development-UNESCO Digital Library. https://unesdoc.unesco.org/ark:/48223/pf0000230514

- UNESCO. (2017). Education for Sustainable Development Goals: Learning Objectives. Division for Inclusion, Peace and Sustainable Development; UNESCO.

- United Nations Economic Commission for Europe. (2012). Learning for the future: Competences in Education for Sustainable Development.

- United Nations Educational, Scientific and Cultural Organisation. (2015). Education for sustainable development. UNESCO Publishing. https://en.unesco.org/themes/educationsustainable-development

- United Nations Educational, Scientific and Cultural Organisation. (2010). Seoul agenda: Goals for the development of arts education.

- Úřad vlády České republiky, Odbor strategického rámce pro udržitelný rozvoj. (2015). Strategický rámec Česká republika 2030.

- Vaish, A., Grossmann, T., \& Woodward, A. (2008). Not all emotions are created equal: The negativity bias in social-emotional development. Psychological Bulletin, 134(3), 383-403. https://doi.org/10.1037/0033-2909.134.3.383

- Wallis, B., \& Tucker, M. (1984). Art after modernism: Rethinking representation. New Museum of Contemporary Art.

- Wals, A. E., \& Corcoran, P. B. (2006). Sustainability as an Outcome of Transformative Learning. Drivers and Barriers for Implementing Sustainable Development in Higher Education, 103. 
- Wals, A. E. J. (2010). Mirroring, Gestaltswitching and transformative social learning. International Journal of Sustainability in Higher Education.

https://doi.org/10.1108/14676371011077595

- Wals, A. E. J., \& Jickling, B. (2009). A framework for young people's participation in sustainability. Young people, education, and sustainable development: Exploring principles, perspectives, and praxis (pp. 77-84).

- Ward, K.S. (n.d.). Creative Arts-Based Pedagogies in Early Childhood Education for Sustainability (EfS): Challenges and Possibilities | Australian Journal of Environmental Education | Cambridge Core. Retrieved 26 June 2019, from https://www.cambridge.org/core/journals/australian-journal-of-environmental-education/article/creative-artsbased-pedagogiesin-early-childhood-education-for-sustainability-efs-challenges-and-possibilities/E2790AFCEF8725F07E7BF6347DB8E20E

- Weir, J. (2016). The Way the Light Hits a Web. Art Education, 69(3), 6-11. https://doi.org/10.1080/00043125.2016.1158568

- White, B. (2009). Aesthetics Primer. Peter Lang.

- Winner, E., Goldstein, T. R., \& Vincent-Lancrin, S. (2013). Art for art's sake?: The impact of arts education. OECD Publishing. https://doi.org/10.1787/9789264180789-en

- Wood, B. E., Taylor, R., Atkins, R., \& Johnston, M. (2018). Pedagogies for active citizenship: Learning through affective and cognitive domains for deeper democratic engagement. Teaching and Teacher Education, 75, 259-267. https://doi.org/10.1016/j.tate.2018.07.007

- World Commission on Environment and Development. (1987). Our common future. Oxford University Press. https://sustainabledevelopment.un.org/content/documents/5987ourcommon-future.pdf

- Wright, T., Markle, G., \& Wuench, P. (2013). The Goggles Project: Using Street Theatre to Engage University Stakeholders in Discussions about Sustainability. Creative Education, 4(07), 105. https://www.scirp.org/html/34869.html

- Wrigley, T., Lingard, B., \& Thomson, P. (2012). Pedagogies of transformation: Keeping hope alive in troubled times. Critical Studies in Education, 53(1), 95-108. https://doi.org/10.1080/17508487.2011.637570

- Yelland, N., \& Arvanitis, E. (2018). Transformative pedagogies in early childhood education. SAGE Publications Sage UK: London, England. https://journals.sagepub.com/doi/pdf/10.1177/1463949117734979 


\section{Př́loha 1: Dotazník pro učitele}

\section{Důvěra ve vlastní pedagogické schopnosti (vybráno z Smetáčková et al., 2017)}

Všechny otázky začínají:

"Jsem přesvědčen/a, že dokážu...".

Respondenti odpovídají na škále nikdy - zřídka - někdy - často - vždy

Předem stanovit kritéria hodnocení tak, aby byla všem žákům jasná.

1. Přizpưsobovat průběh a náplň hodiny nečekaným změnám.

2. Vysvětlit hlavní myšlenku vyučované látky tak, že ji pochopí všichni žáci.

3. Rozvrhnout obsah předmětu tak, aby se stihlo probrat vše, co je ve vzdělávacím programu.

4. Učit tak, že děti mají dobré znalosti a dovednosti.

5. Ukázat dětem smysluplnost probíraného učiva.

6. Volit takové vyučovací metody, které nejlépe odpovídají vyučované látce.

7. Motivovat žáky k práci na obtížných úkolech.

8. Připravovat rozmanitý a zároveň vyvážený výukový program.

9. Motivovat žáky tak, že si o tématu sami zjišt́ují doplňující informace.

10. Vhodně kombinovat různé způsoby hodnocení žáků.

11. Motivovat $\mathrm{k}$ učení i méně úspěšné děti.

12. Přijmout konstruktivní kritiku od svých kolegů.

13. Spolupracovat s ostatními vyučujícími na zkvalitňování výuky.

14. Vyměňovat si navzájem se svými kolegy zkušenosti a postřehy.

\section{Vzdělávání pro budoucnost}

Následující položky reflektují dosavadní průběh projektu.

Odpovídejte na škále:

souhlasím - spíše souhlasím - nejsem si jistý/jistá, jak se rozhodnout - spíše nesouhlasím - nesouhlasím

1. Žáci participovali na volbě tématu společného projektu.

2. Žáci participovali na volbě způsobu realizace společného projektu.

3. Žáci při realizaci projektu aktivně pracují s vizí své budoucnosti.

4. Projekt vede žáky $\mathrm{k}$ zamyšlení nad jejich životem.

5. Projekt aktivně rozvíjí kompetence, které jsou jinak ve škole na okraji zájmu.

6. Žáci při realizaci projektu aktivně využívají a rozvíjejí kritické myšlení.

7. Žáci v projektu aktivně pracují s tématem udržitelnosti.

\section{Zdroj:}

Smetáčková, I., Topková, P., \& Vozková, A. (2017). Vývoj a pilotáž škály učitelské self-efficacy. Lifelong Learning - celoživotní vzdělávání, 7(2), 26-46. https://dx.doi.org/10.11118/lifele2017070226. 